\title{
前立腺癌の電顕像に及ぼす去勢の影響
}

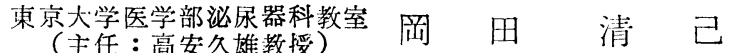

\section{ULTRASTRUCTURAL CHANGES OF THE PROSTATIC CANCER CELLS BY CASTRATION}

\author{
Kiyoki Okada \\ The Department of Urology, Faculty of Medicine, The University of Tokyo.
}

(Director: Prof. H. Takayasu)

Prostatic cancer cells are known to be shrunken after castration or antiandrogenic treatment. In this paper electron micrographs of normal prostate, benign prostatic hypertrophy, prostatic cancer cells and castrated prostatic cancer cells were demonstrated.

Specimens were obtained from 3 healthy persons, 3 cases with benign prostatic hypertrophy and 8 cases with prostatic cancer. In cases of prostatic cancer, the pictures of cancer cell were compared before and after castration.

In normal prostatic gland, tall columnar epithelia developed well. These cells were separated from stroma by a basement membrane. Along the basement membrane, basal cells were scattered, which appeared to have no secretory function. In glandular cells, round or oval nuclei were present at the basal region. Endoplasmic reticulum, mitochondria, secretory granules and vacuoles were observed in the cytoplasm. In benign prostatic hypertrophy internal structures of the cell did not differed significantly from those in normal prostate. As to cancer cells it was sometimes difficult to differentiate malignant cells from normal ones. However, the most prominent feature of prostatic cancer cell was shown by changes of nuclei which were featured by irregularity of the nuclear membrane and increases in number and size of nucleic chromatins. Numerous cytoplasmic organelles, especially endoplasmic reticulum and mitochondria were seen to be scattered in the cytoplasm. Prostatic cancer cells were observed to destroy the basement membrane and invade into the surrounding connective tissue. The most evident effect of castration on the cancer cells was collapse of endoplasmic reticulum and mitochondria, and degeneration of the cancer cell at the end stadium. Numerous cytoplasmic inclusion bodies were seen, which appeared to be transformed from mitochondria and endoplasmic reticulum. After castration, mature and immature collagen fibers were noted throughout the prostatic tissue around the fibroblast. These findings are considered to be the effect of castration.

\section{緒 言}

前立腺は性ホルモンの刺激に反応することからホルモ ン依存性の器官といわれている，前立腺癌は悪性腫瘍と に一の性質，“自律性”を有し，同時に本来の前立腺と しての性質，“ホルモン依存性”をいまだ保持している。 Huggins 等 25) 25) 27)（1941）により完成された前立腺癌 の治療法である抗男性ホルモン療法は前立腺癌のホルモ ン依存性という性質を応用して行つた方法で今日最も重 要な治療法とされている．前立腺癌のこの抗男性ホルモ ン療法に関しては幾多の臨床的, 内分泌学的, 病理組織 学的研究について, 数々の興味ある論文が発表されてい
る. しかし病理組織学的な立場での抗男性ホルモン療法 の機序については, 現在でも尚不明な点が多い. 抗男性ホルモン療法による光学顕微鏡（以下光顕と称 す)的变化として, 癌細胞の退行变性及び間質の増生があ る. 退行変性として (1)癌細胞及び核の大きさ, 数の減 少 $\left(\right.$ Fergusson $\left.{ }^{18) 19}\right)$ ), (2)核濃縮, 核融解 (Schenken $\left.{ }^{45)}\right)$, (3)細胞質の空胞化 $\left(\right.$ Schenken $\left.^{45)}, \mathrm{Heckel}^{23)}\right)$ ，(4)線維 化を伴う腺様構造の消失 (Fergusson) 等があげられて いる. 抗男性ホルモン療法のらち去勢術による变化とし て著明にみられるのは癌細胞の退行变性であるといわれ

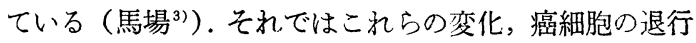


変性及び間質の増生を電子顕微鏡でとらえてみたらどう であろらか。

電子顕微鏡（以下電顕と称す）の生物学への応用は 比較的新しく, 現在でも病理学への応用は少い. 前立腺 に関する抗男性ホルモンの変化を電顕的にとら充た研究 は小動物に於て行われている. Harkin ${ }^{22)}$ (1957)，山口 ${ }^{59)}$ （1960）はラットを用いて去勢の影響を見ており，Harkinによれば，ラット Ventral prostate の特徵は 細胞 質小胞体にあり，去勢後 4〜6 日で小胞体の萎縮を観察 し，山口るほぼ同様な所見を得ている。

現在まで前立腺癌に関する論文はTakayasu \& Yamaguchi $^{\text {53) }}$ (1962), Brandes et $\mathrm{al}^{8)}$ (1964) 等があり, 前 立腺癌の特徵として采粒优の変化が述べられている。し ふし前立腺癌の去勢による影響を電顕的にとらえた論文 は見当らない。

著者はまず成人正常前立腺, 前立腺肥大症腺腫, 前立 腺癌, 去勢後の前立腺癌を電子顕微鏡にて観察し, 次の 二つのことについて考察した（1) 前立腺癌の特徵はど の様なものであるか（2)去勢により前立腺癌はどの様 に退行変性し，又間質は增生するであろらか。

\section{試料作成法}

(1) 対象及び採取法

対象は正常成人, 前立腺肥大症, 前立腺癌（無処置）, 前立腺癌去勢後 7 日，14日の患者である.

（1）正常前立腺：3名. 前立腺炎の疑いで生検して し，光顕で正常であつたものをえらんで行つた.シルバ ーマン針により経直腸式生検にて採取す。

（2）前立腺肥大症： 3 名. 前立腺剔出術後電顕用に 固定. 光顕にて前立腺肥大症腺腫で, 悪性像は見られて いないものである。

（3）前立腺癌： 8 名.すでに光顕にて腺癌と診断さ された患者より採取した，方法は開放性会陰式生検又は シルパーマン針による経直腸式生検である.

（4）去勢後 7 日の 前立腺癌：（3)の患者のらち 5 名. 開放性会陰式生娭又は経直腸式にて採取した。

（5）去勢後14日の 前立腺癌：（3)の 患者のうち 2 名. 経直腸式生検にて得る。

これらの試料は電顕用のみでなく，併せて光顕用にも 使用した。

（II） 作成法

（1）固定：採取後ただちに $0 \sim 2{ }^{\circ} \mathrm{C}$ 温度で, 鋭利 なカミソリにて $1 \mathrm{~mm}^{3}$ 以下の大きさに細切し， $2 \sim 4{ }^{\circ} \mathrm{C}$ に冷さ礼心固定液中心入れ穴，固定液は Palade ${ }^{40)}$ の方
法による醋酸ベロナール緩衝液を含む $1 \%$ 四酸化オスミ ウムで pH 7.4に調製した固定液を用いた．固定時間は約 1 時間半である.

（2）脱水：上昇エタノール系列で行う. $75 \% 15$ 分. $85 \% 15$ 分. $95 \% 15$ 分. $100 \% 5$ 分 2 回,つづいてPropyren oxide10分 2 回. Propyren oxide：Epon 混合液 1：1を 30 分. $1 ： 2$ 液と 2 時間. Epon 混合液に24時間浸漬し た。

（3）包埋：Luft ${ }^{33)}$ 法にて Epoxy 樹脂を用いて包 埋した. $37^{\circ} \mathrm{C} 1$ 昼夜, $45^{\circ} \mathrm{C} 1$ 昼夜. $60^{\circ} \mathrm{C} 1$ 昼夜放置し重 合さ然心。

（4）薄切：LKB 製超ミクロトームにガラスナイフ を用いて超薄切をつくる. 厚さは. 300〜 800Aで，Strip 法にて 150/Inc ${ }^{2}$ 銅メツシュを用いて切片をのせた.

（5） 染色：Watson ${ }^{60)}$ の方法にて醋酸ウラニウム飽 和溶液に約 1 時間放置し, 終了後蒸溜水にて洗滌した.

（6）検鏡：明石製 TRS $50 \mathrm{~F}$ 型電子顕微鏡又は日立 製HUIIA型電子顕微鏡を用い，直接倍率 $2,000 \sim 20,000$ 倍にて写真撮影す。それらを適当な大きさに昖大して観 察所見を得た。

\section{観察所見}

（I）正常前立腺細胞（図 1 ）

（1）一般的所見：前立腺細胞は光顕像に見られるよ らに一層又は二層よりなり腺胿をとりかこんでいる，細 紐胞の配列は比較的規則正しい．上皮細胞である基質 と膠原線維を含む間質とは基底膜 Basement membrane (BM) で完全に境されている，上皮細胞には二種あり， 腺腔に面した分泌器官を含む腺細胞と, 基底膜に隣接し た基底細胞がみられる。まず腺細胞より観察する。

（2）細胞膜：腺細胞はやや円柱状で腺腔に向つて突 出している.腺腔に向う細胞遊離縁にはMicrovilli $(\mathrm{Mv})$ と呼ばれる小突起を有している。隣接細胞との接触面で 細胞遊離縁では Terminal bar ( $\mathrm{Tb}$ ) と呼ばれる電子 密度の高い部分があり．それより細胞間をたどつていく と, 所々に再び電子密度の高い Desmosome (Des) と呼 ばれる部分が存在している。 その間には細胞膜の深くお れまがつた Interdigitation (ID) があり，よく発達し ている。これは細胞が三つ出会う部分に特に多い。

（3）核 Nucleus(N)：中心部より基底部に近い所に あり，型は円型ないし棈円形で不規則な型を示すものは ない，核質は不規則な電子密度を示さず，ほぼ均等な小 顆粒より成つている。核小体 Nucleolus(NI) はNucleolonema と呼ばれる網状構造より成つている，明らか沉 
核質より電子密度が高い，核クロマチン Nucleic chromatin $(\mathrm{Nc})$ はこの四酸化オスミウム固定では検出され ていない.

（4）細胞質：系粒体 Mitochondria（M）は細胞質 全体に散在している. 型は棈円形ないし桿状型を示す. その内部にはクリスタと呼ばれる糸粒体膜の突起が出て いる. 系粒体基質はやや細胞質基質より電子密度が高い. ゴルジ体 Golgi body (G) も核上野にみられる．小胞 体は粗面小胞体 Rough surface endoplasmic reticulum (rER) 及び滑面小胞体Smooth surface endoplasmic reticulum (sER)が共に存在して扮り,特に粗面小胞体は全 域に存在している。しかしラット上皮細胞でみられる同 心円状の粗面小胞体は存在しない，分泌顆粒 Secretory granule $(\mathrm{Sg})$, 分泌空胞 Secretory vacuole (Sv) (黒 住 $\left.{ }^{32}\right)$ と呼ばれている分泌器官が散見できる. 特に分泌 空胞は層状になつて集合している，これらは滑面小胞体 と呼んでよいと思う。

（5）基底細胞 Basal cell (BC)：腺細胞と異なると 思われる細胞が腺細胞と基底膜の間にある，核は大き く，核型は不規則で invagination が強い，核質も腺細 胞のそれより電子密度が高い，核小体は存在している。 細胞質小器官は少く，所々に系粒体が見られる．基質は 密でやや暗い，分泌器官はほとんどない。

（II） 前立腺肥大症腺腫細胞（図 2）

（1）一般的所見：前立腺肥大症の細胞は正常細胞に 近い，細胞は円柱状で配列は規則正しい，基底膜に隣接 して基底細胞もみられる.上皮と間質とは入りまじるこ とはない。

（2）細胞膜 : 腺腔に向う細胞遊離縁で Microvilliが みられる. Terminal bar, Desmosomeる存在している. Interdigitation も発達している.

（3）核：泀ぼ円型ないし棈円型を示す．正常なもの と比較すると核型はやや不規則である。しかし非常に強 いinvagination はない，核質では，正常では見られな かつた核クロマチンが核内，核周辺縁部に散在してい る。核小体は不明である。

（4）細胞質：系粒体は数は少いが散見される。クリ スタは明膫で，破壊されているのは少い，ゴルジ体，小 胞体も見られる. 分泌顆粒, 分泌空胞も存在している. その他, 正常組織でみられた基底細胞も前立腺肥大症の 場合にもみられた。

（II） 前立腺癌細胞（図 3～困 9)

（1）一般的所見 : 癌細胞一つを観察した時は正常細
胞との比較は困難であるが組織として見た時は光顕て覞 察される像が著明にみられる。細胞の配列が乱れ，基杢 的な単層上皮として存在する所は少い，基底膜が破填出 れて上皮と間質とが入り乱れてくる.

（2）細胞膜：一部ではかなり基本的な腺細胞を有 する細胞もみられる（図3，4）.Microvilli愔正常細胞よ りやや多い Terminal bar, Desmosome も存在する Demoso meの破壊像はみられず，ほ注正常である（図 8 ）. Interdigitation 性正常細胞では多く見られたが，癌では やや少い(図 4 ).

（3）核：二種類の核が観察される。一つは目立つ程 不規則な型をなしていない，円型又は棈円型で，正常 核に比し, invagination が認められる。電子密度も正 常で核小体は存在し，核クロマチンは明らかでない（図 3,4). ᄂかるにもう一つの核は前者にくらべやや小さ い. 核型は非常に不規則で入りくんでいる。すな方ち invaginationが強い，核質の電子密度は細胞質のそれに 近いが，不規則である。核の辺縁部及び中心部に核ク口 マチンが多数みられる。核小体も膨化した如学像学呈 し，典型的な Nucleolonema は見られぎ，核クロマチ ンと区別がつかなくなつている（図5, 6 ).

（4） 細胞質 : 沢山の小器官が存在している. 系粒体 は症例により異なるが，系粒体の数は正常細胞にくらべ 多い（図 5)。それらの系粒体を観察すると比較的形態 の維持されているのもあるが，かなり変形し polymorph である.形は一般に桿棒状というより円形でやや膨化し ている。クリスタも断裂しているのが認められる（図 5 ).しかし去勢後の系粒体注ど变化はしていない.ゴル ジ体は正常像でみられるのと同じく核上野に存在する。 小胞体は粗面, 滑面共に存在し（図6), 特に粗面小胞体 はよく発達している（図6,7 ).典型的な像を図 7 亿示す が，粗面小胞体が胞状となつて存在し，限界膜の外側に RNP 顆粒が配列している。滑面小胞体は小胞状空胞と なつて存在する。しかし粗面，滑面共正常像よりやや膨 化又は小胞状である. free RNP 顆粒淙細胞内に多数存 在し, 前立腺癌の一つの特徴となつている。 その他細胞 質内に去勢後多く見られる Cytoplasmic inclusion body (Cib) も見られる.それらは系粒体の破壊された像の如 きものを含み形は不定である（図 6)，この小器官は去樊 後に多くなるが，処置前の前立腺癌にも存在している. 一例のみに見られたものに，らずをき状の小器官 Cytoplasmic inclusion $(\mathrm{Ci})$ がある (図 9 ). この小器官は, Virus であるという説もあるが，この成因については後 
述する. 又細胞啠に小線維 Tonofilament がみられてい 。(図 4 )

（5）間質組織：癌組織の特徵ある所見として細胞の 配列の乱れを挙げることができる。それと同時におこる 線維組織の乱れである．基底膜は破壊され癌細胞は間質 に浸潤する，そのため癌細胞間に膠原線維がみられてく る(図6)。

その他, 正常前立腺, 前立腺肥大症において観察され た基底細胞は認められない。

（IV）去勢後 7 日の前立腺癌細胞（図10～図17）

（1）一般的所見：去勢後一週間の電顕像によると全 部の癌細胞が一度に変化するのではなく, 術前とほぼ同 じ形態を示するのから（図10，11）,著しい変化をらけて いる癌細胞まで各種の像が観察される（図13，15）.变化 は核の一部にも見られたが，最も強い变化をうけている のは細胞質の小器官である.

（2）核：核は一般に変化が少い（図11）.しかしある 細胞の核は, 処置前の癌細胞に比して小さく, 核型の不 規則性もなく，核クロマチン，核小体も見当らない，核 質子電子密度低く粗である（図15）。一部の核膜の破壞も みられる（図14）。しかし光顕像で去勢後に見られる核濃 縮は認められなかつた。

（3）細胞質：系粒体は变化が強い.ほほ処置前の系 粒体に近い形をし太ものから（図11），完全に去勢の影響 をらけて変形した系粒体も見られる。最も多く見られる のは糸粒体の膨化であつて形は大きく円形になる，クリ スタは断裂したり細切化されて小胞状になつているのも 見られる（図10，14，16）.又他の糸䊉体の变化として小 型で濃縮した様になり型を変形して奇妙な型を示す。基 質も電子密度が高い。しかしクリスタは尚保持されて いる（図12，13，15）.小胞体は粗面，滑面共に変化し数 が少くなる. 粗面小胞体では比較的形態の維持されてい るものも一部にみられるが，多くは小胞状に細切化され る（図13，15，16）. 又その表面の限界膜についている RNP 顆粒もばらばらになり，消失している部分もある (図15).又膨化して円形状になつているのも認められる （図10）.滑面小胞体も径約 $500 \AA$ 飞細切化されたものか ら径約 $1.5 \mu$ に膨化したもの（図15）も又られ処置前に くらべ明らかに变化している. 細胞質内 free RNP 顆 精も明ら亦に少く然り，細胞が明かるくなつている（図 13，15).ゴルジ体は処置前と变りないものも存在する. しかし多くは膨化し，ゴルジ空胞は小胞状空胞となつて 散在する (図12，13）.細胞質小器官の変化としていわゆ る Cytoplasmic inclusion body の増加が認められる。
空胞中に, 系粒体様のものを入れた小器官が存在する （図12，13，16).これらは何に由来するのか不明である が，怖らくは糸粒体，小胞体の変形したものと考兄られ

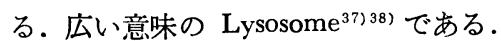

この様に去勢により電䫓像に種々の変化がみられた。 これらの変化のうち，核が小型で粗で，細胞質は稀薄 で, 系粒体, 小胞体の変化が強く Cytoplasmic inclusiom body の見られる明かるい細胞が散見できる．核，細胞 質の变化の強い細胞で，退行変性を扎こしたと考光変性 細胞 Degenerated cell (DC) と著者は呼ぶ（図13，15）。

（4）間質組織 : 去勢後一部の癌細胞内へ細い、線維の 存在が認められる。これは Tonofilament (Tf) である と思われる（図16）.径約 $300 \AA$ 以下で，横絞は認められ ない，去勢前にもみられたが，とこに挄いて放数も增玑 している様に思われる。

膠原線維は明らかに増殖する。これら膠原線維を観察 すると次の二つのものがあげられる．すなわち一部の組 織にFibroblast 及び二種の間質線維を認めることができ る（図17）.一つは巾約 $700 \AA$ で附近に横絞が認められ る. 他の一つは前者に比較すると小さく $300 \AA$ 以下の線 維で横絞を認めない，この小さな線維，すなわち幼若線 維 (Ic) は, 細胞内 Tonofilament と形態的に同じすの かどうか確定できない，これらは去勢後に出現したとい うことは容易に観察される。

（V）去勢後14日の前立腺癌細胞（図18，19）

（1）一般的所見 : 去勢後 2 週間の变化は間質の増殖 が非常に強くなることである．まだ去勢前に近い癌細胞 も存在しているが，大部分は癌細胞と間質とは入り乱 れ，癌細胞の破壊されている所もみられる.

（2）核：比較的小さく，核型はあまり不規則ではな い，核質はほほ均等で核クロマチン，核小体はみられな い.

（3）細胞質：糸粒体はほとんどが基本的な型を示さ ず, 膨化，クリスタの断裂，クリス夕の細切化が著明で ある. 小胞体も粗面, 滑面共飞細切化, 膨化し原型をと どめない，細胞質内の一部にゴルジ野と思われる所があ り。そこにはゴルジ膜，ゴルジ架胞がばらばらに残つて いる（図19）。 free RNP 顆粒は少く，粗面小胞体附近 にあるのみである. その他Cytoplasmic inclusion body も認められる。一般に細胞質小器官は少くなつている。

主なる所見は膠原線維が非常に多く，細胞の間まで入 つている。ここでも 7 日後と同様に二種の間質線維を認 めることができる．14日後の所見は 7 日後の所見を強調 した型ででている. 


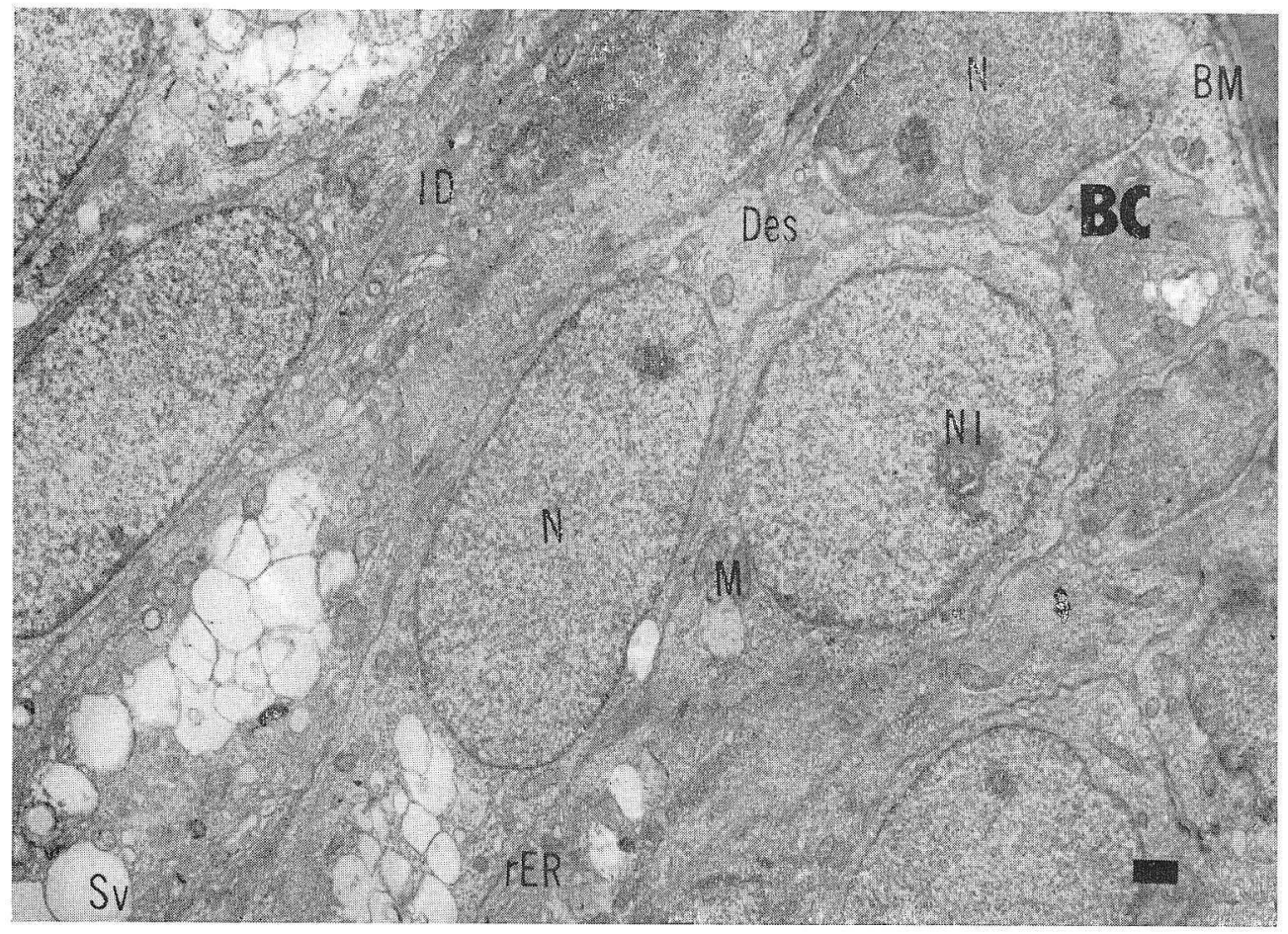

図 14,500 倍

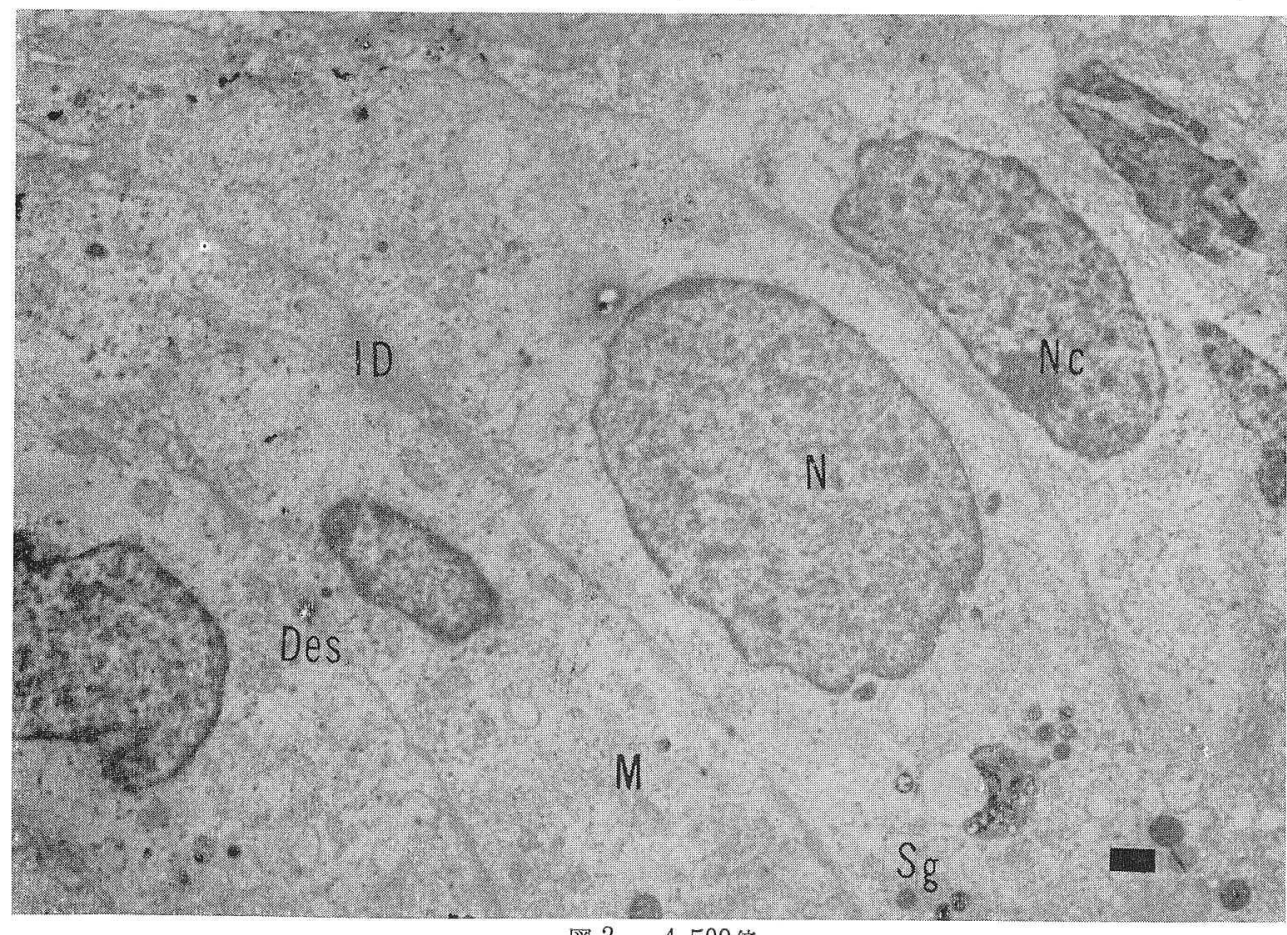




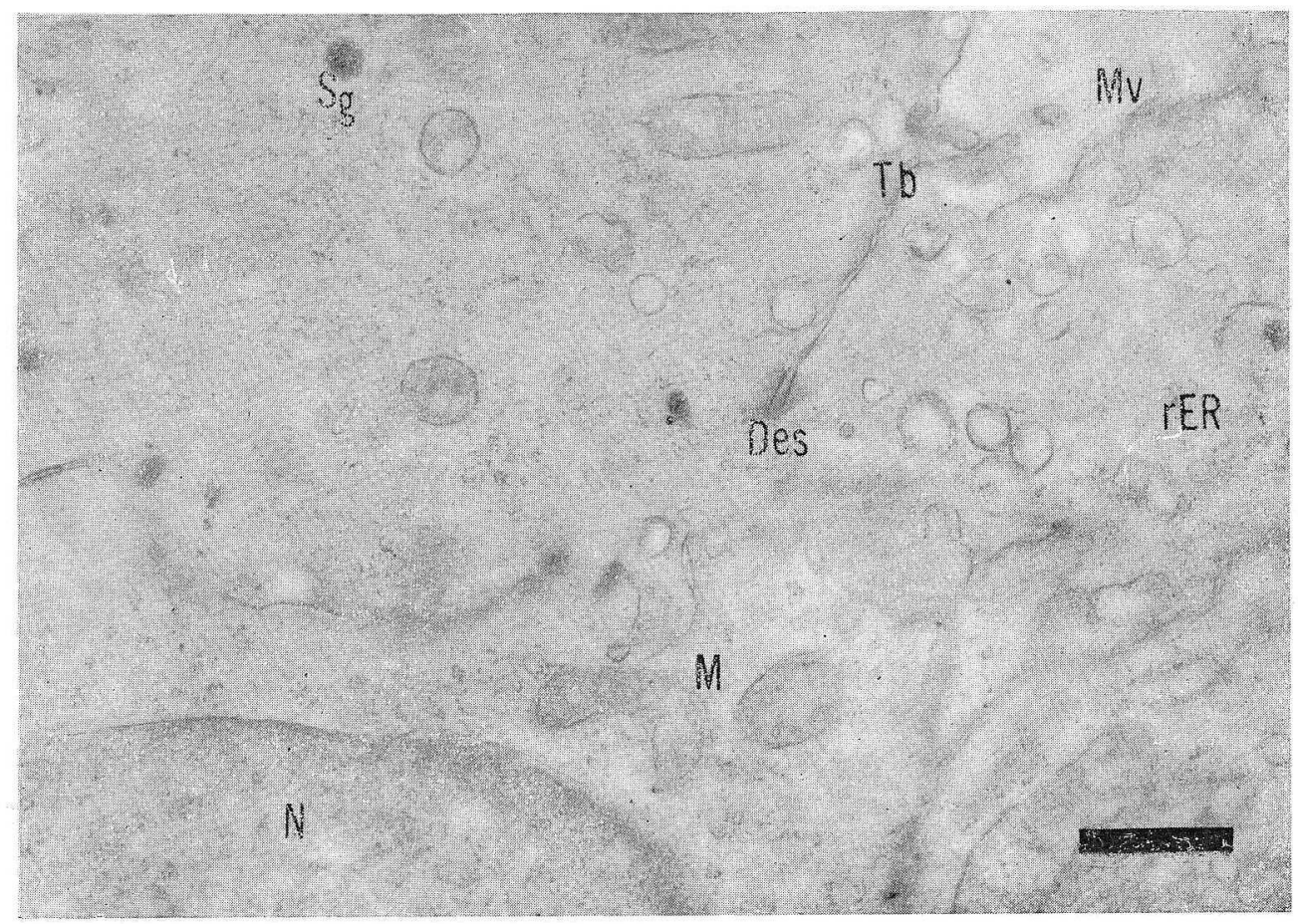

図 $3 \quad 15,000$ 倍

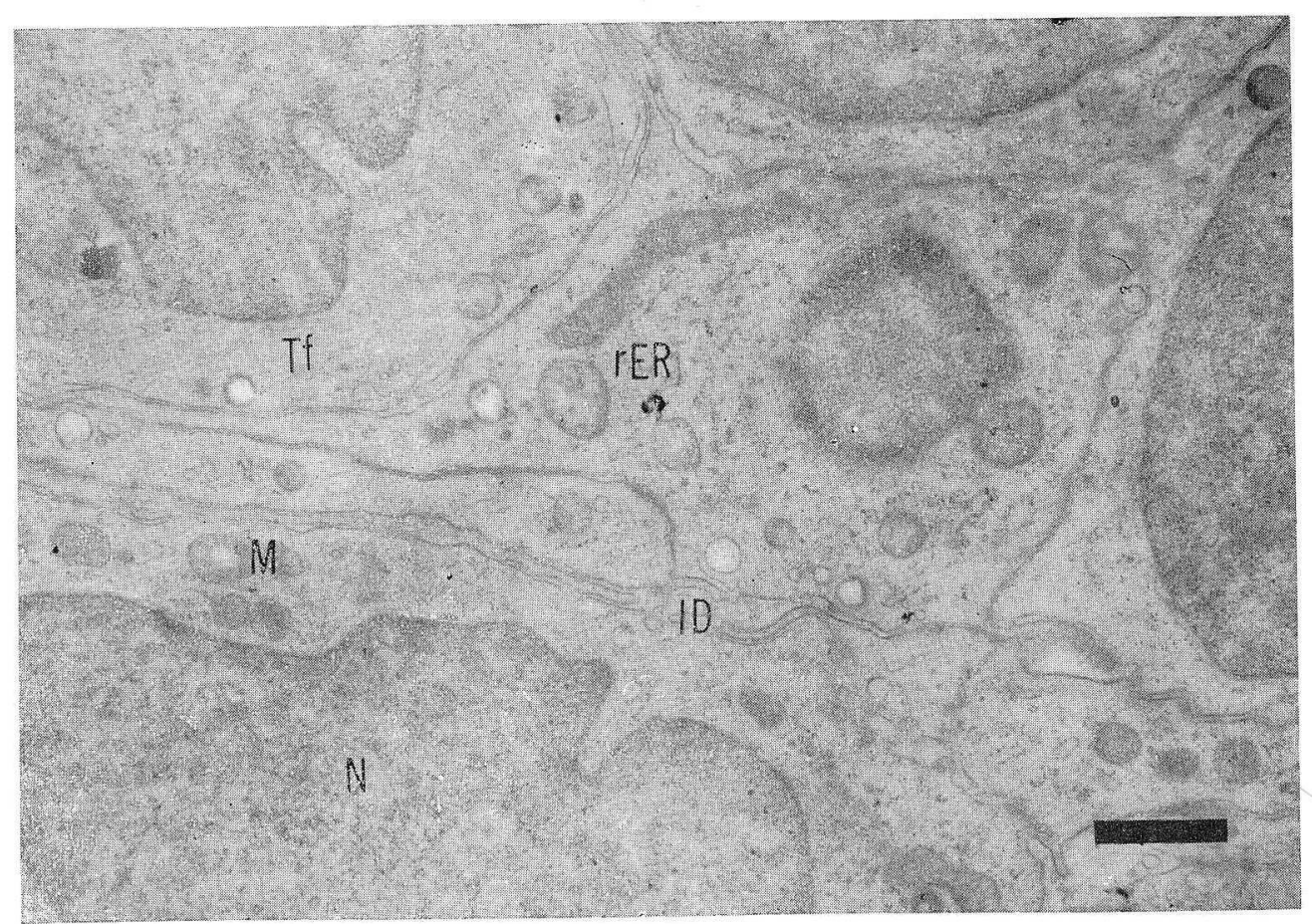

図 4、13,000倍 


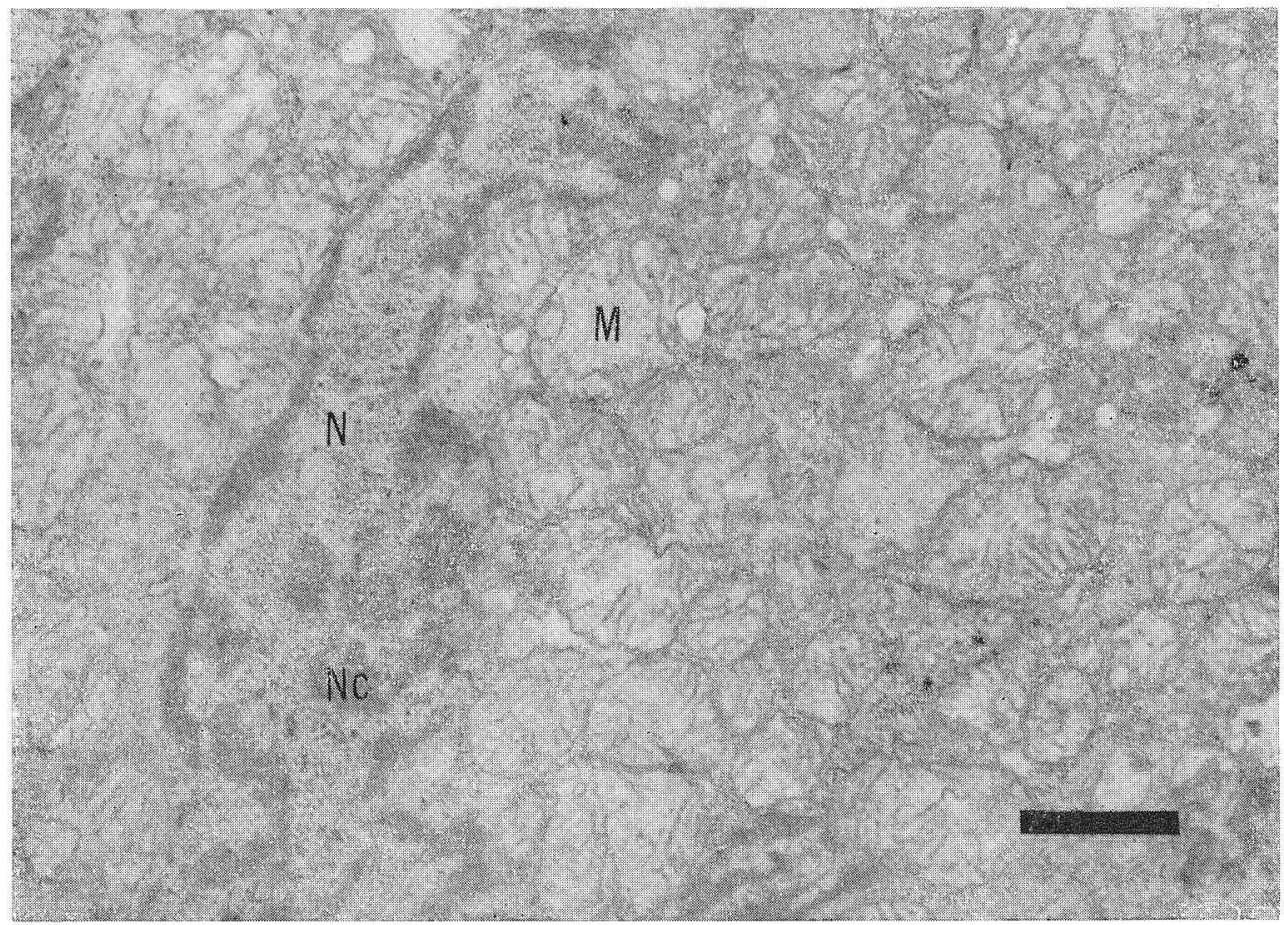

図 $5 \quad 16,000$ 倍

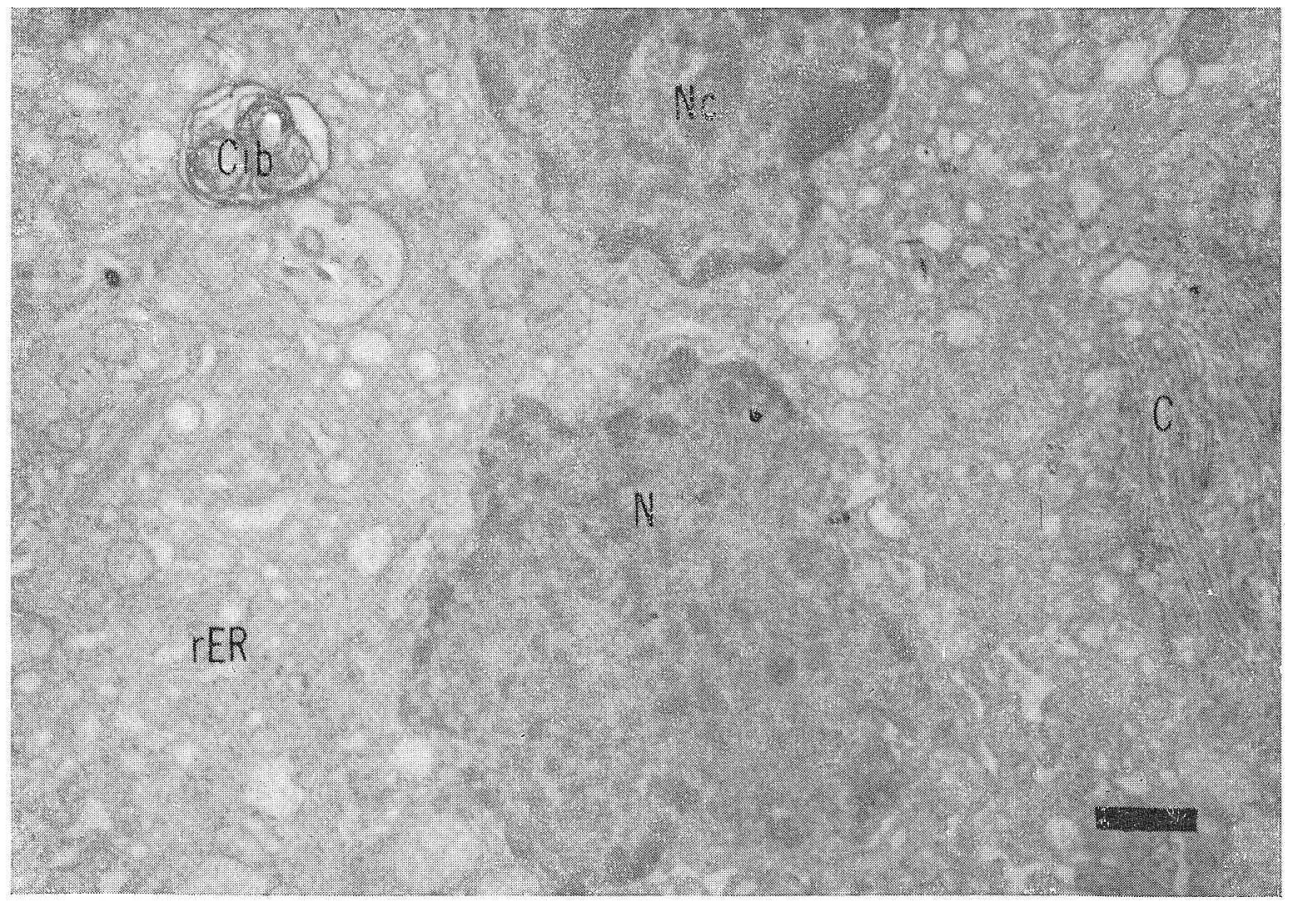

図 610,000 倍 


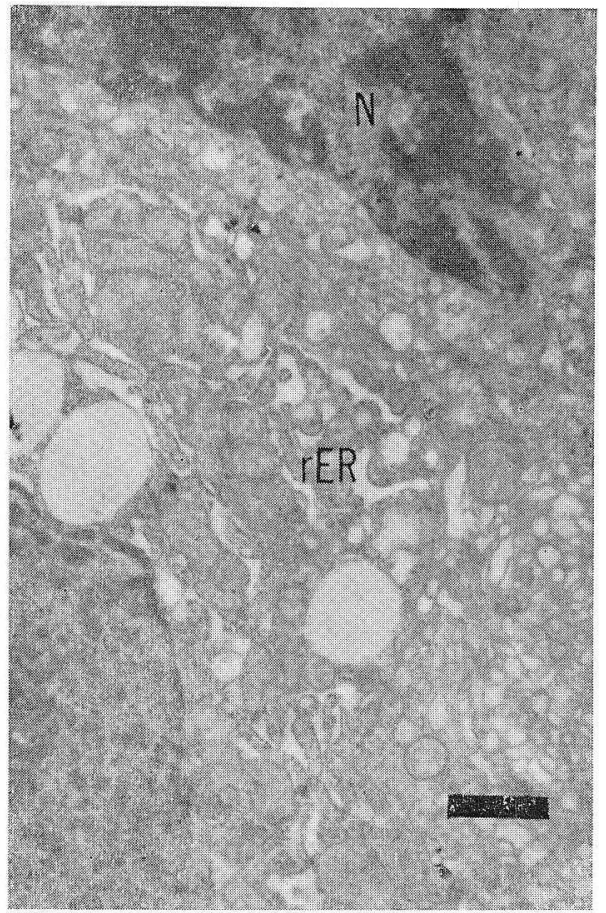

図 710,000 倍

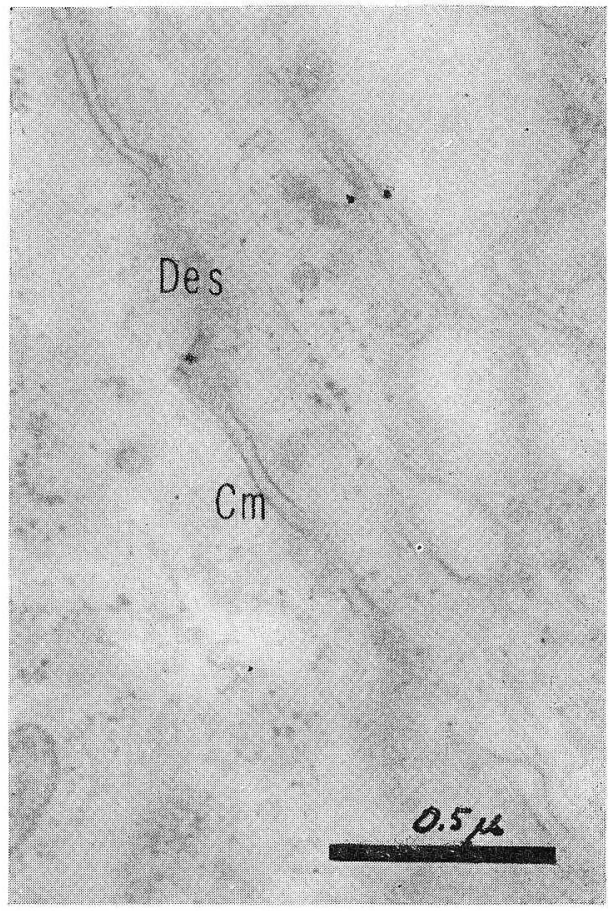

図 846,000 倍

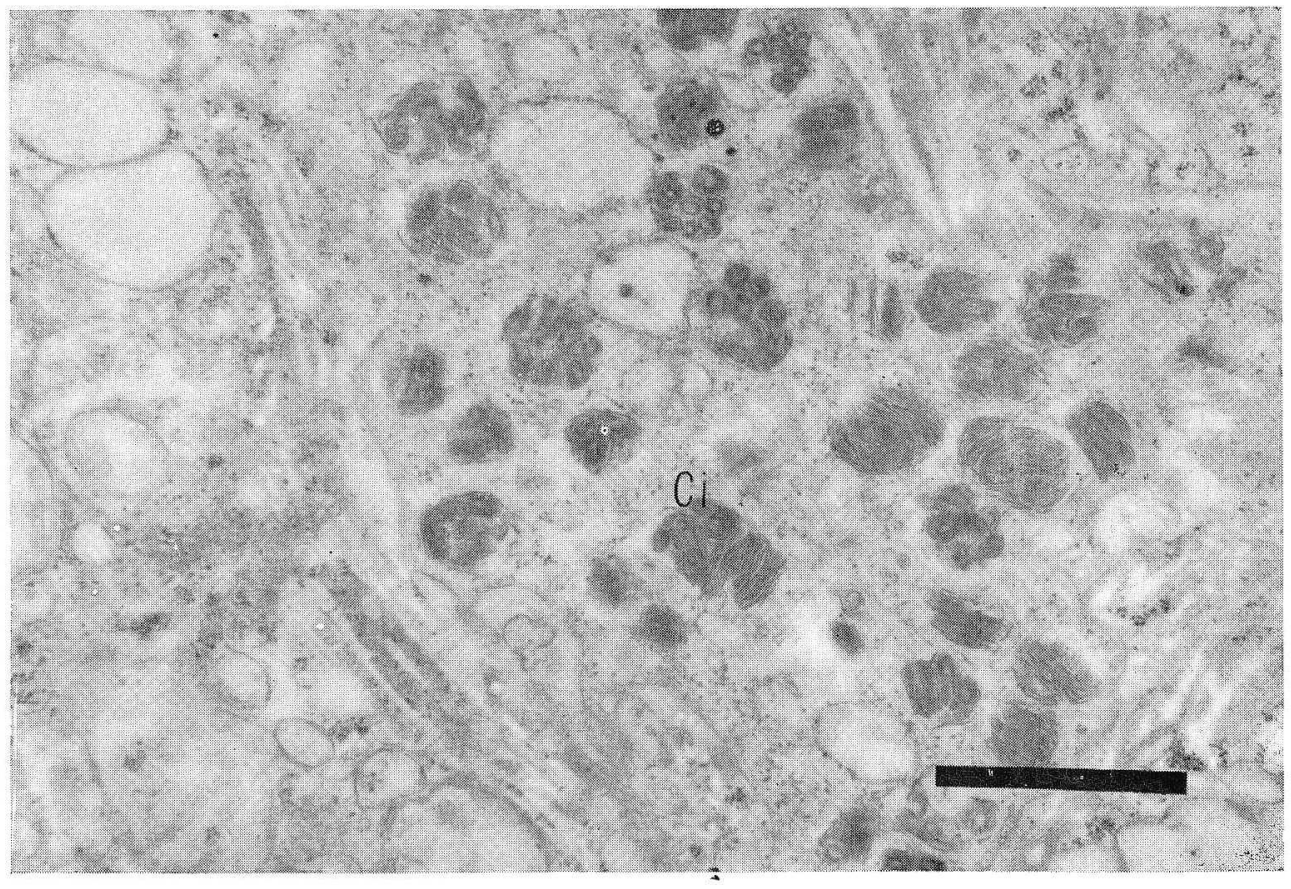

図 925,000 倍 


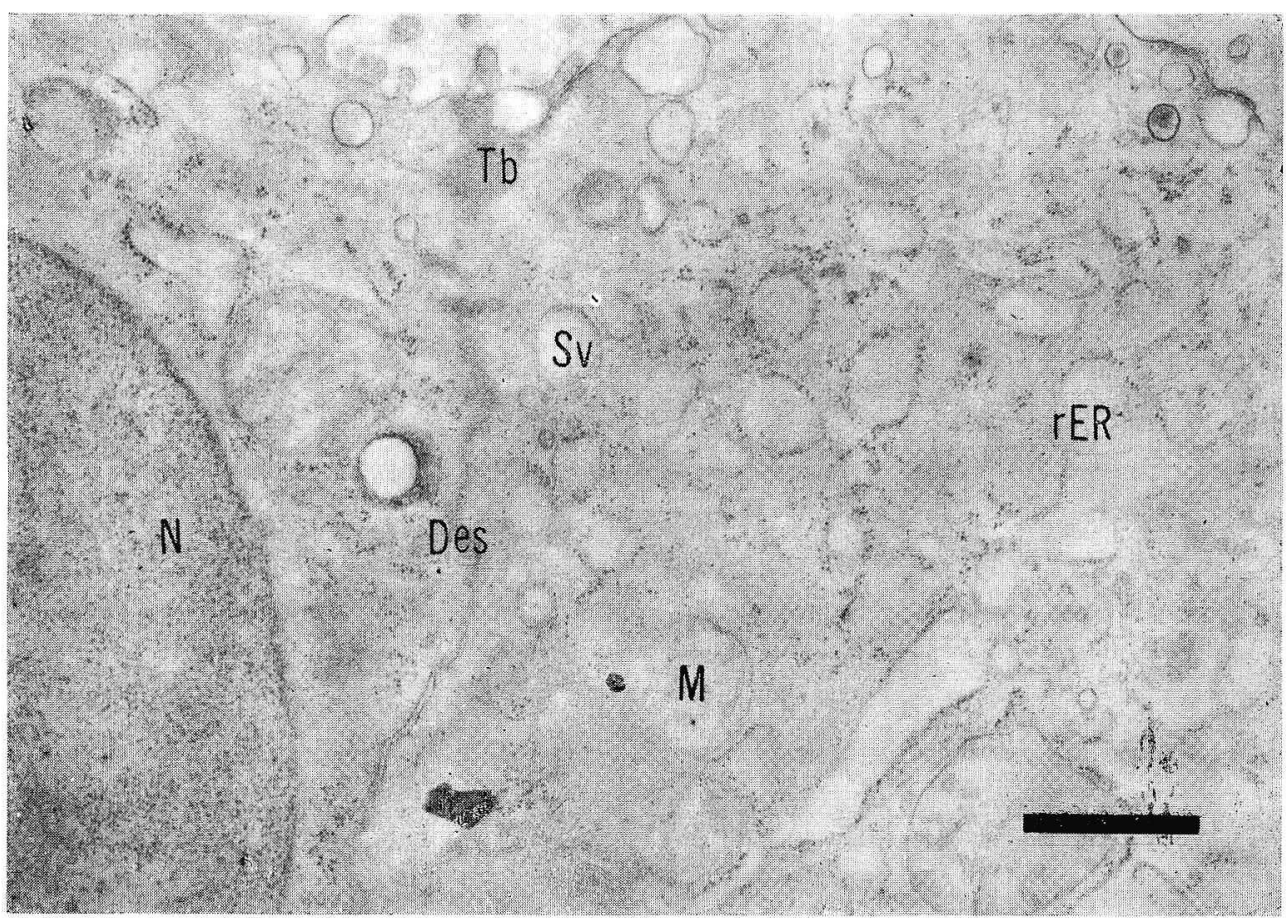

図10 17,600倍

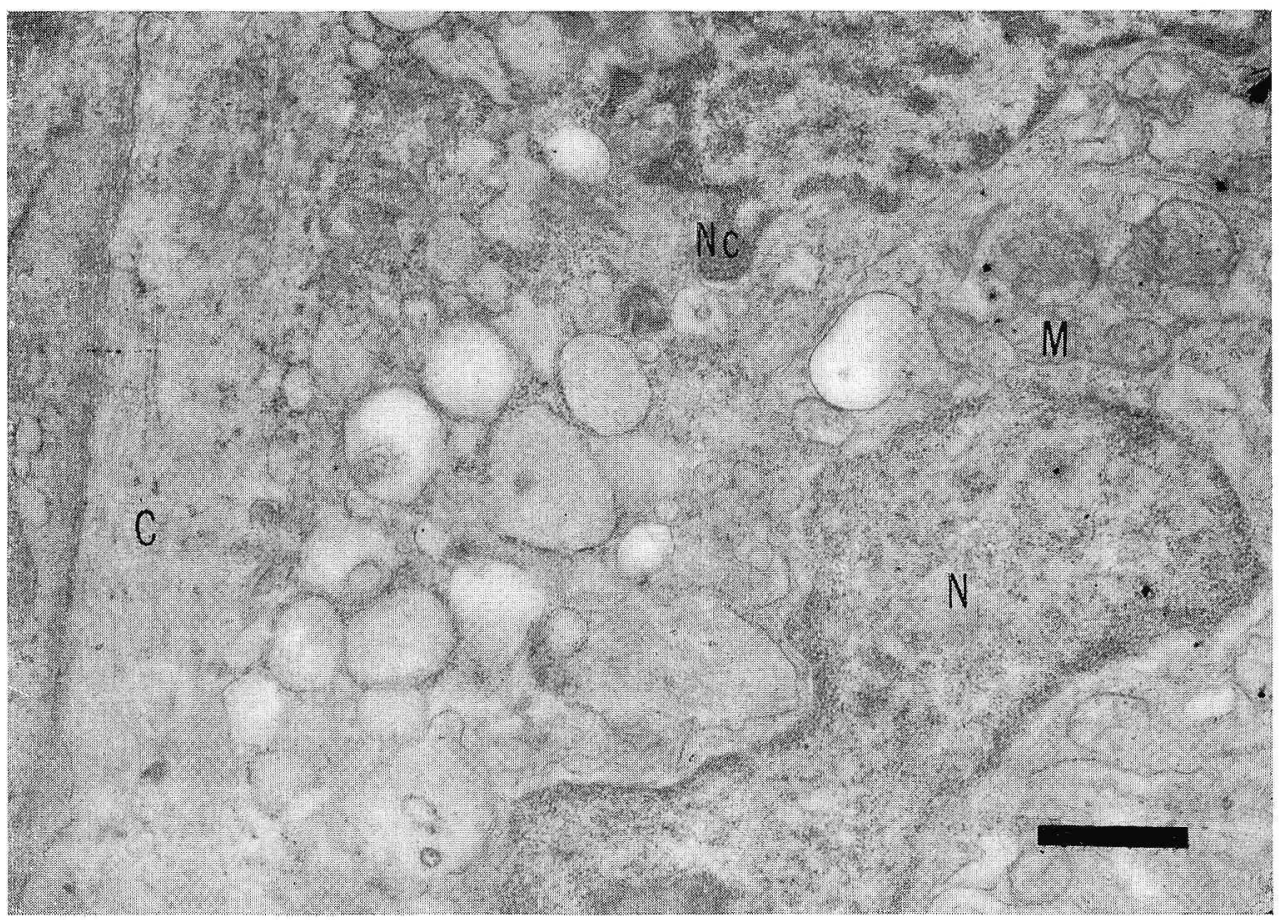




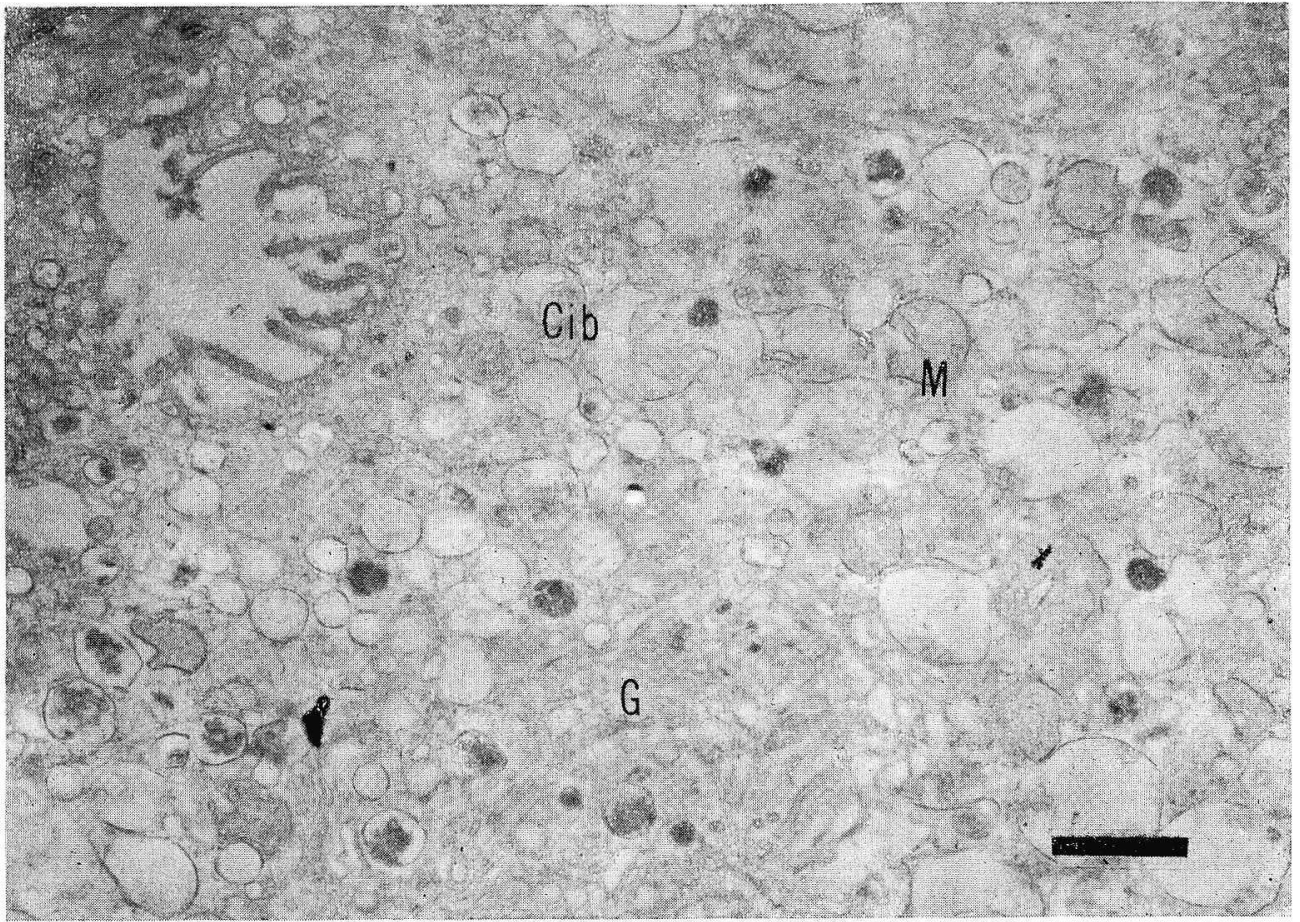

図12 13,000倍

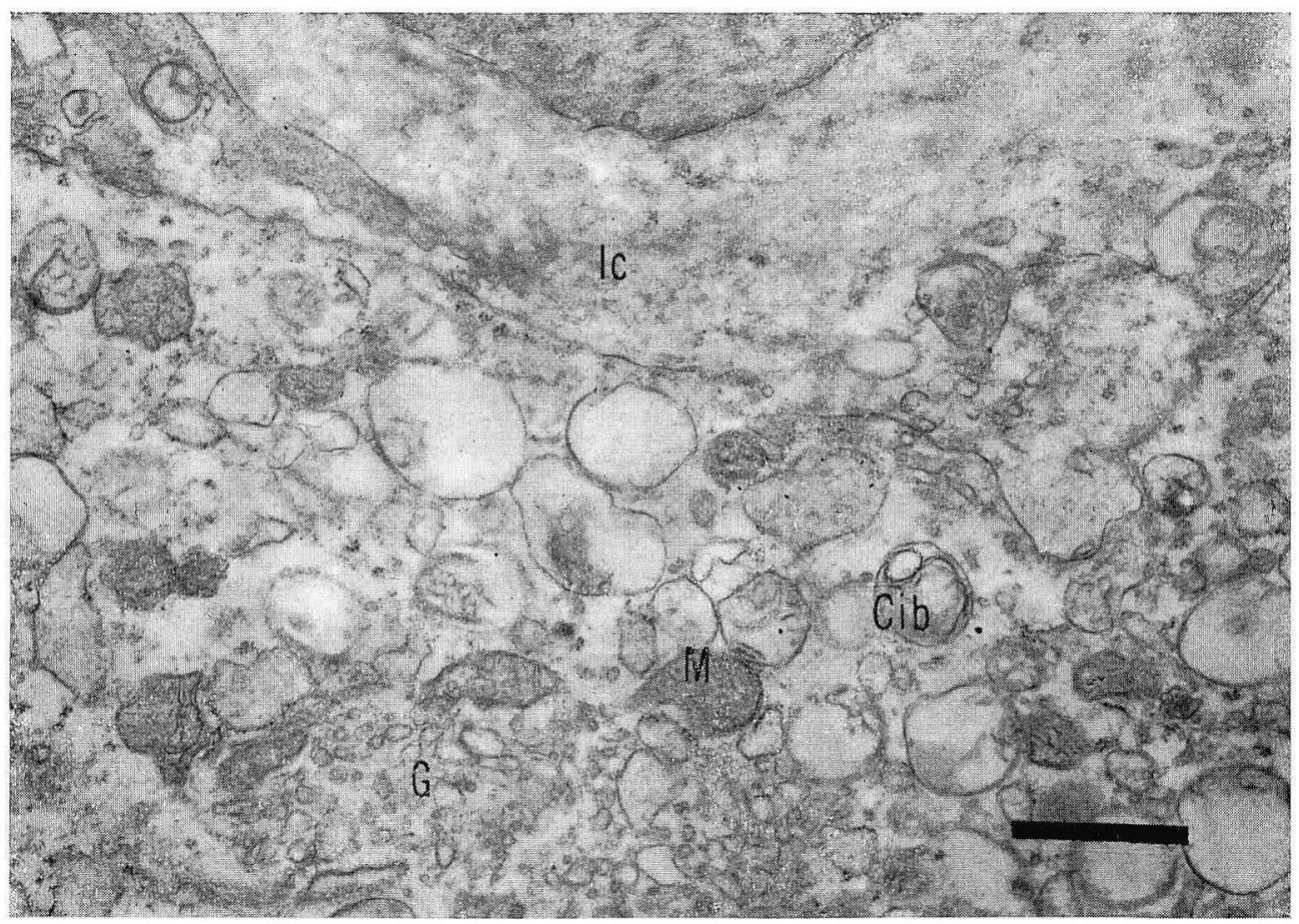




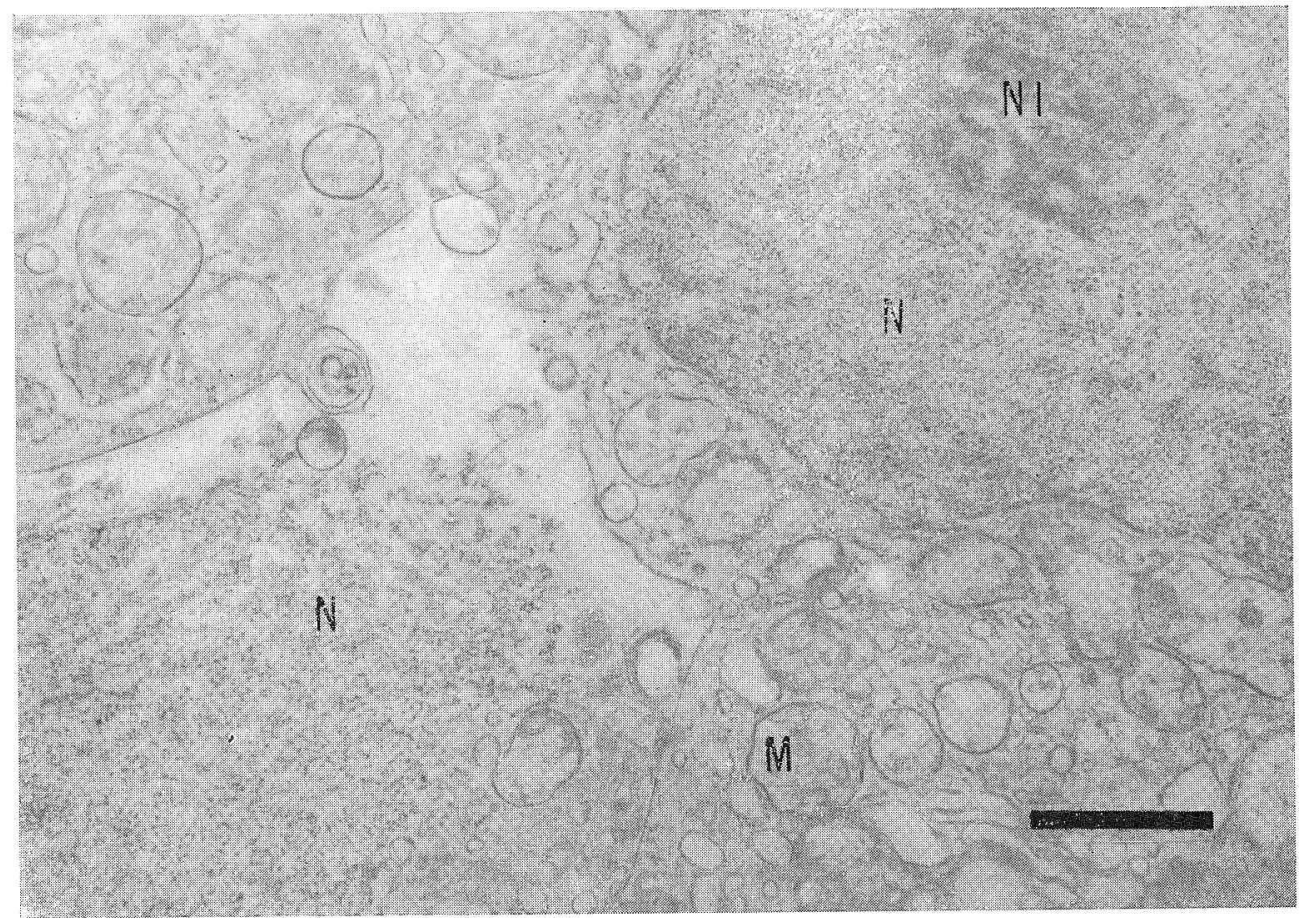

図14 18,400倍

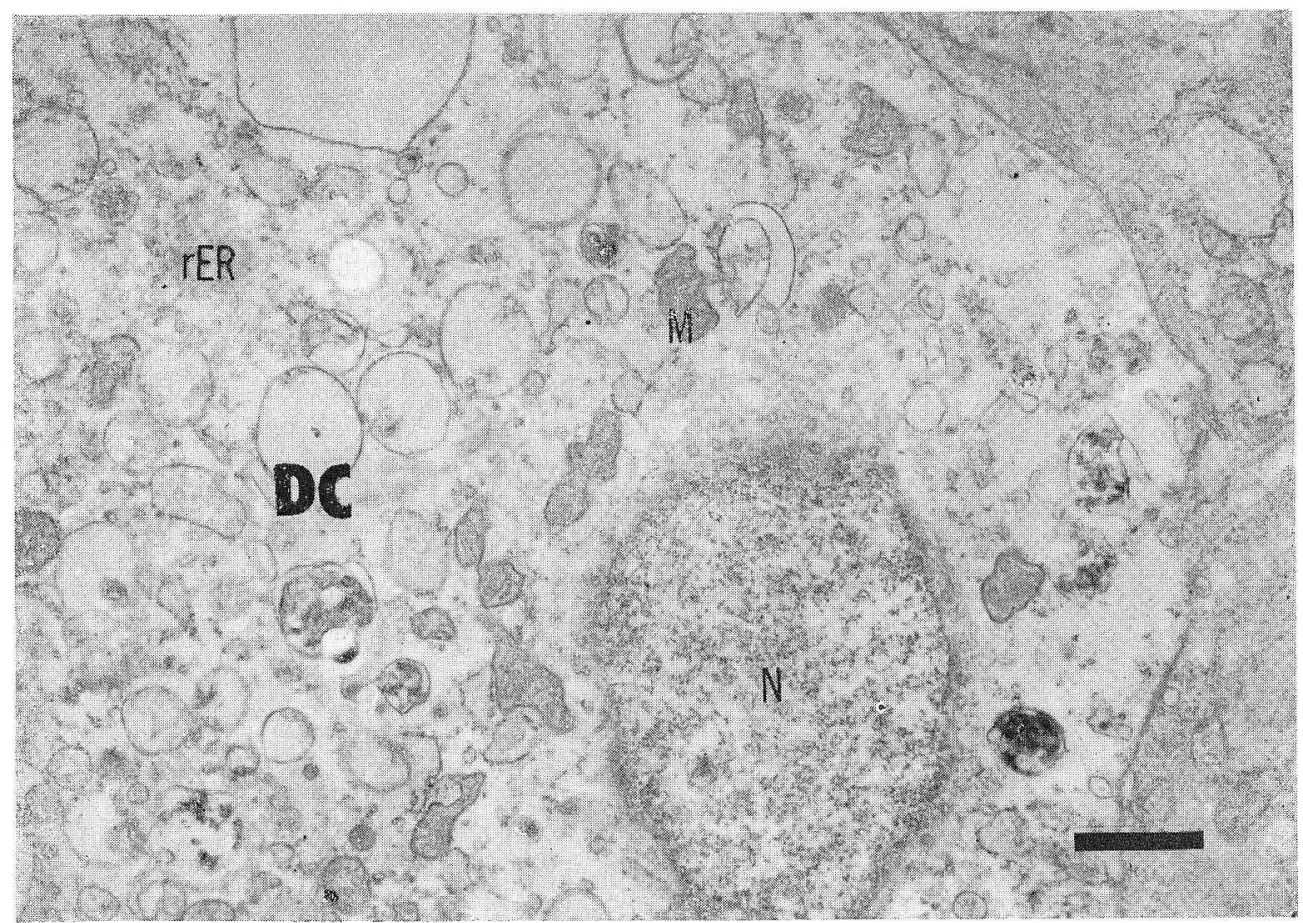

図15 13,000倍 


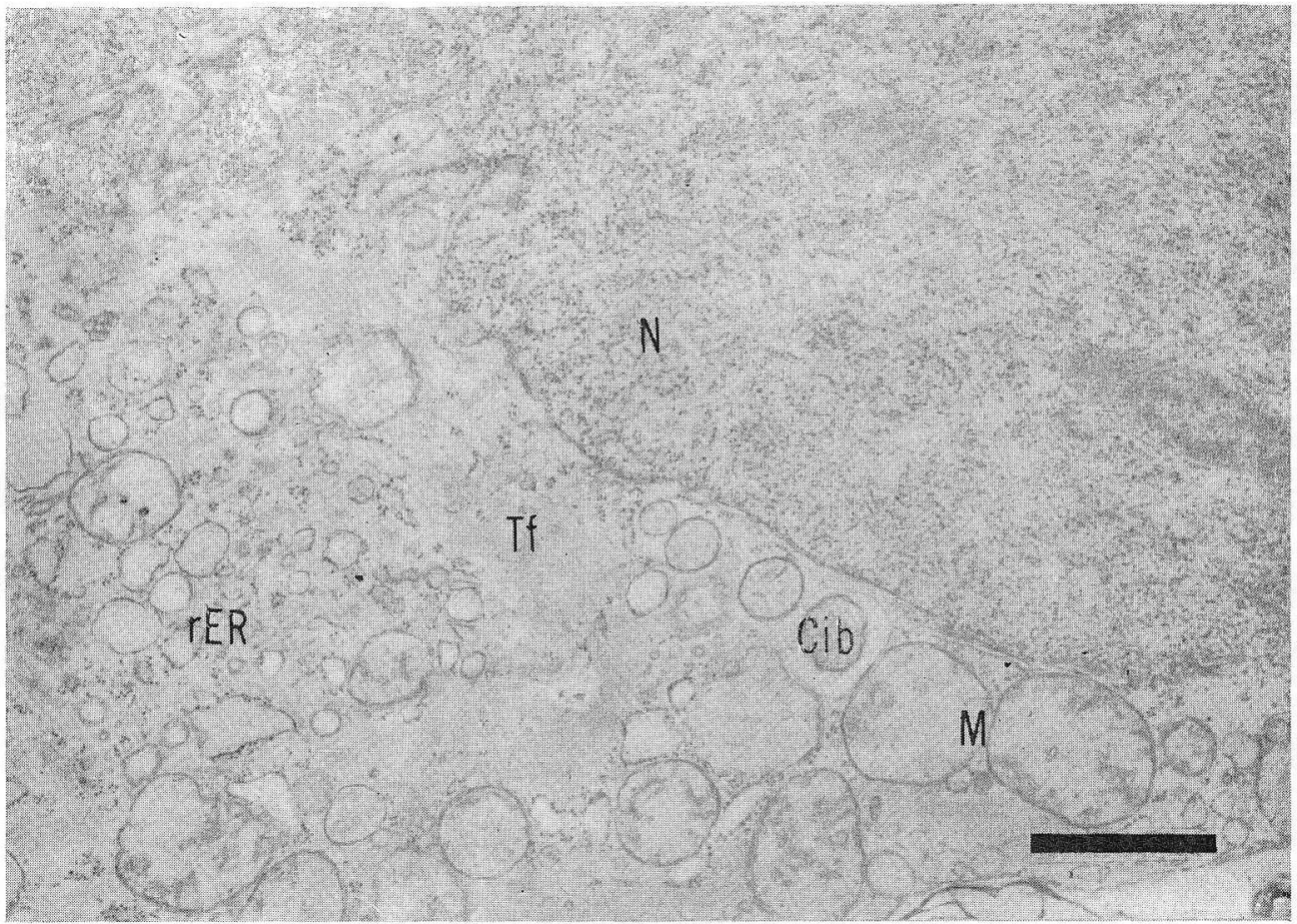

図16 18,400倍

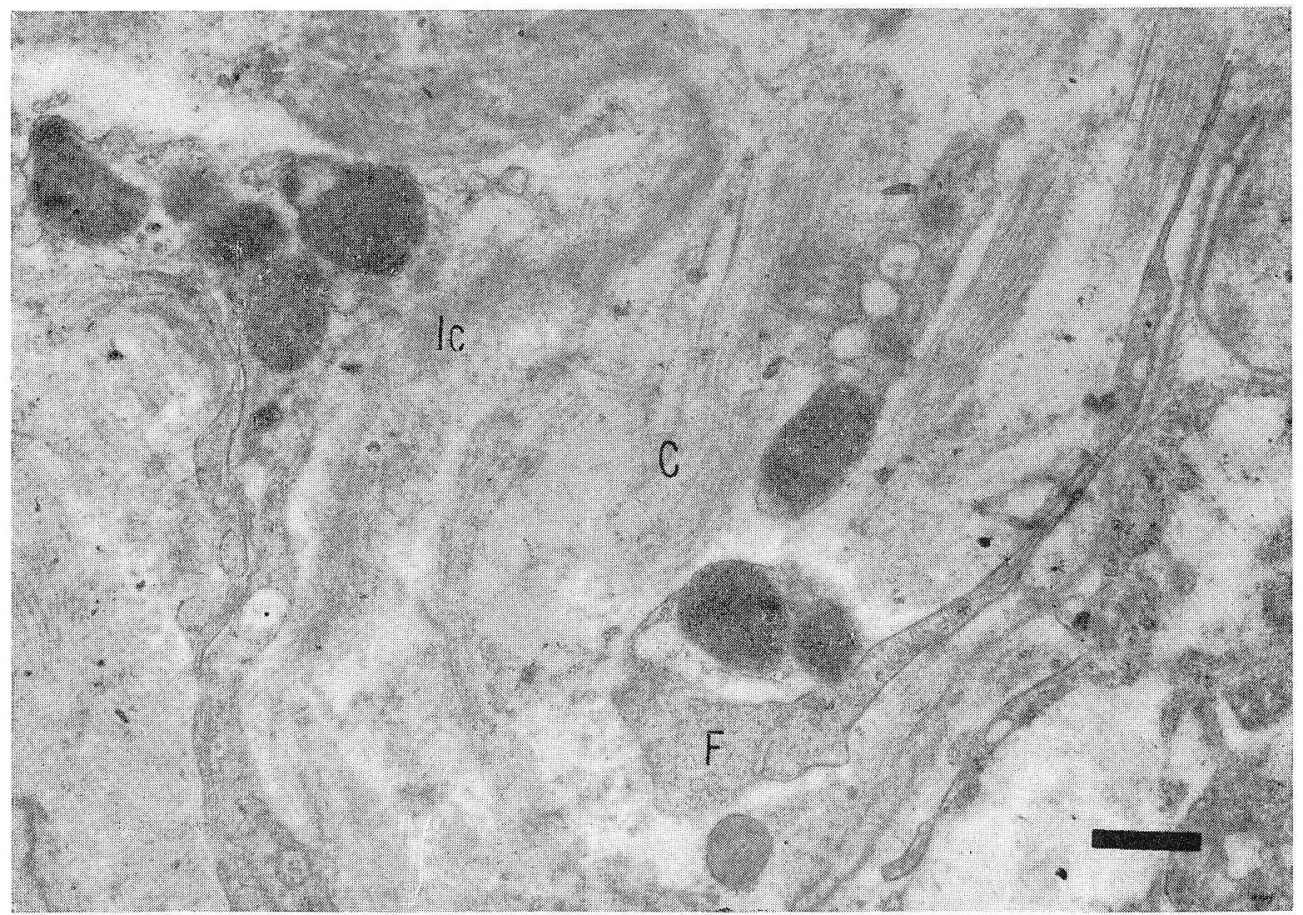

図17 10,500倍 


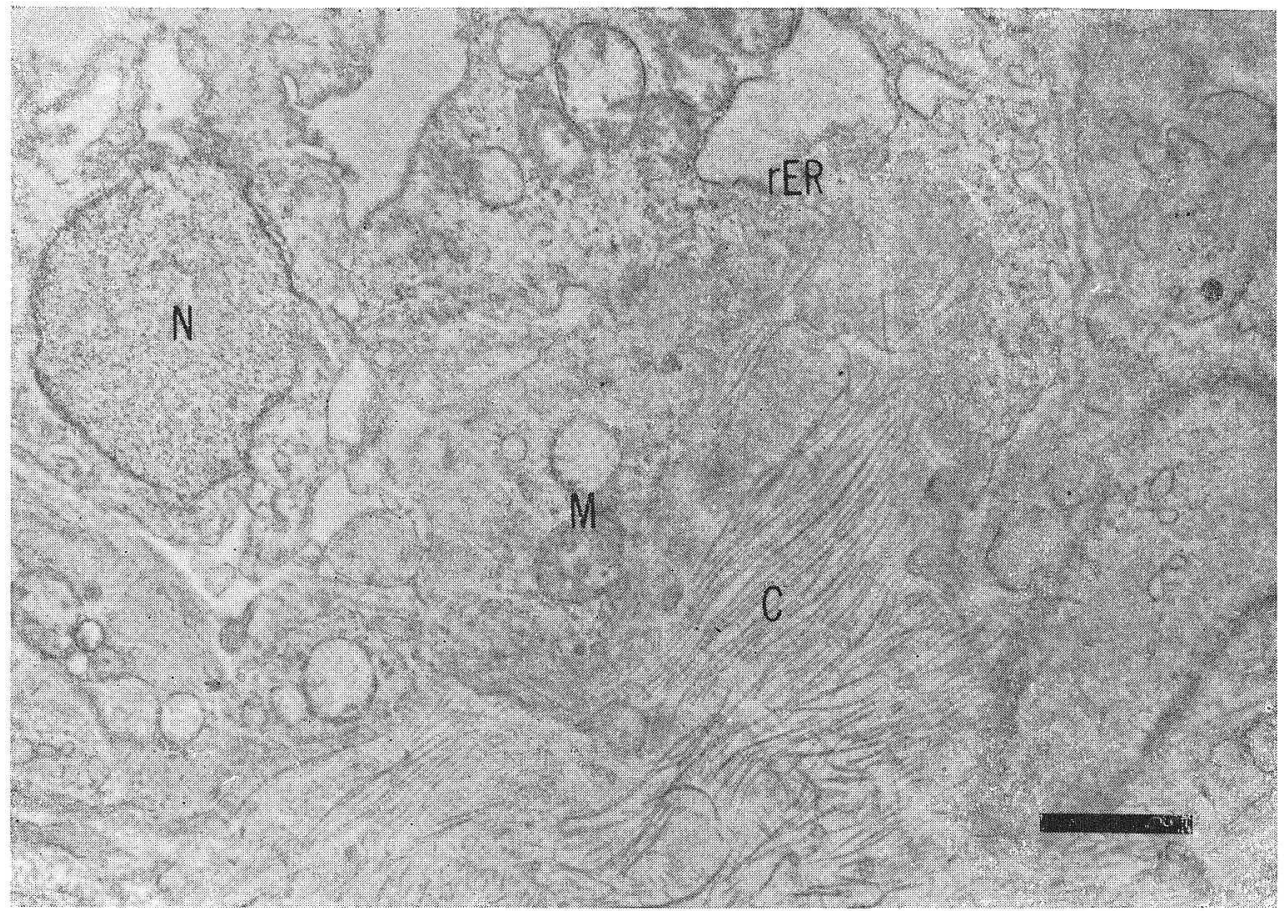

因18 15,600 倍

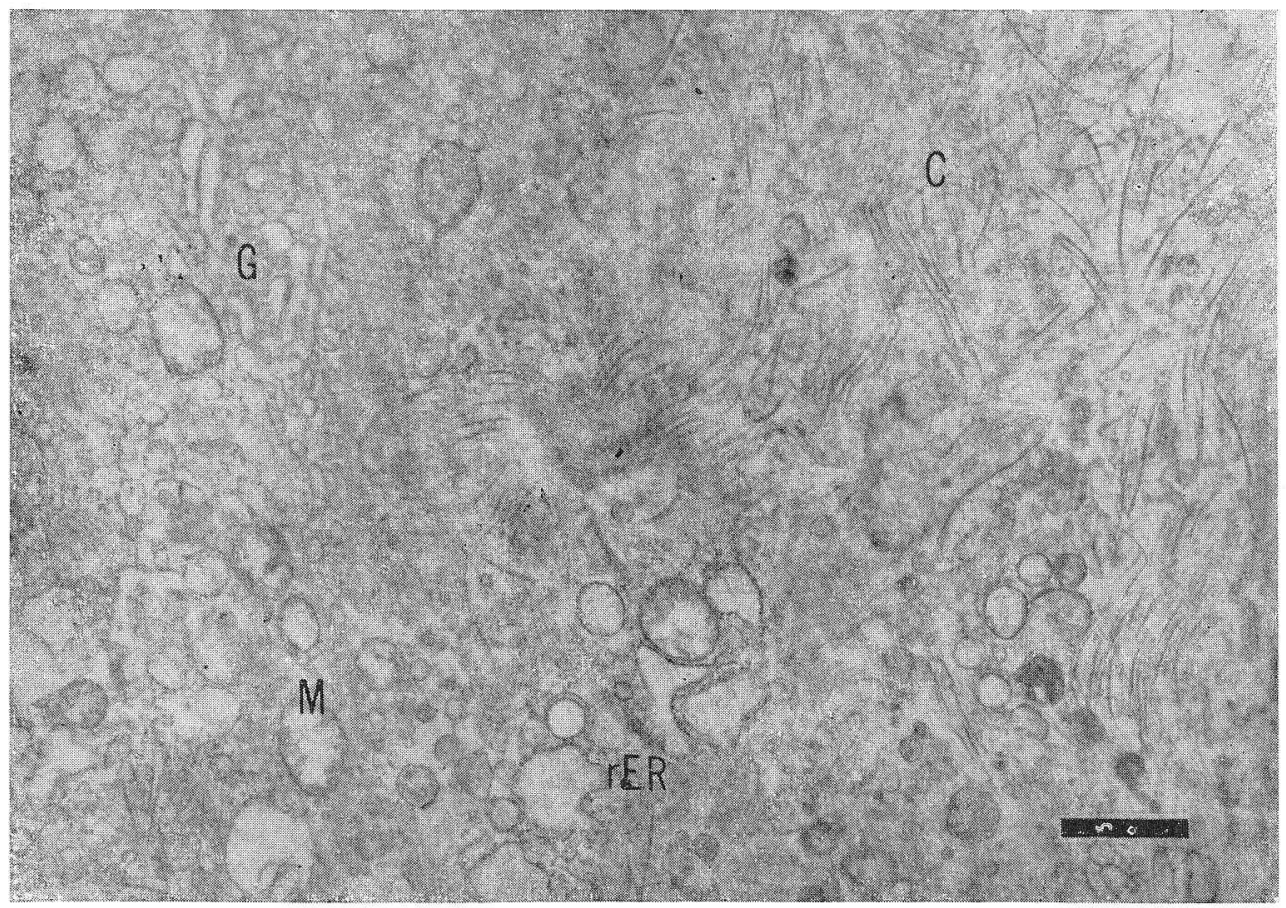


写真説明

\author{
$\mathrm{N}:$ 核 \\ $\mathrm{Nl}$ : 核小体 \\ Nc: 核クロマチン \\ M：系粒体 \\ rER：粗面小胞体 \\ $\mathrm{Sv}$ ：分泌空胞 \\ $\mathrm{Sg}$ ：分泌顆粒 \\ $\mathrm{Ci}$ : Cytoplasmic inclusion \\ Cib: Cytoplasmic inclusion body \\ Tf: Tonofilament \\ CM：細胞膜 \\ $\mathrm{BM}$ ：基底膜 \\ ID: Interdigitation \\ Mv: Microvilli \\ Tb: Terminal bar \\ Des: Desmosome \\ $\mathrm{BC}$ ：基底紐胞 \\ DC：变性科胞 \\ $\mathrm{C}$ ：翏原線維 \\ Ic：幼若膠原線維 \\ F：線稚芽細胞 \\ Scale は $1 \mu$ を示か. 圀 8 のみ $0.5 \mu$.
}

図 1 : 正常前立腺稩胞. 腺稩胞は円柱状で核 (N) は 基底部にある。核内に核小体（N I ）が存在している. 紐胞質では粗面小胞体 (rER), 分泌空胞 ( $\mathrm{Sv}$ ) が著明に 見られる。紐胞間で Interdigitation (Id) が多数あり 腺細胞に隣接して基底細胞（B C ）がみられる. 間質は 基底膜（BM）により境されている。 × 4,500

図 2 : 前立腺肥大症腫腫稩胞. 核 $(\mathrm{N})$ はや〉不整形 になる。核クロマチン（BM）がみられる。細胞間には Interdigitation (Id). Desmosome (Des) が存在してい る. 細胞内には系粒体 (M), 分泌顆粒 (jg) が所々に ある. × 4,500

図 3 : 前立腺癌細胞. 腺腙に向つて Microvilli (Mv) があり，細胞間に Terminal bar ( Tb), Desmosome (Des) が存在している. 糸粒体（M）はほとんどが正 常である. 粗面小胞体 ( $\mathrm{rER}$ ). 分泌顆粒 ( $\mathrm{Sg}$ ) も見ら れる. $\times 15,000$

図 4 : 前立腺癌細胞縦断面. 細胞間の Interdigitation (Id) は少い，系粒体 (M), 粗面小胞体 (rER) が存在 する. 細胞内に Tonofilament がみられる、 $\times 13,000$

図 5 : 前立腺癌細胞. 核 (N) は奇妙な形を示し核ク 口マチン (Nc) も多数みられる. 系粒体 (M) は多数 存在し, 大部分は膨化し円形になつている・クリスタの 断裂，破壊もみられる。 $\times 16,000$

図 6 : 前立腺癌細胞. 核内には核クロマチン ( Nc) が多い。湅胞質では粗面小胞体 (rER) が豊富である。 左.上部に Cytoplasmic inclusion body (Cib) がみられ

る. 右㑡に胗原線䧽が存在す。 $\times 10,000$

因 7 : 前立腺癌稩胞. 粗面小胞体 (rER) がよく発達 している. $\times 10,000$
因 8 ：前立腺癌科胞膜. Desmosome（Des）を示す.

数す正常と变りなく破壤像みられず。 $\times 46,000$

因 9 : 前立腺癌組穖内にみられた Cytoplasmic inclusion (Ci). 5ずまき状のすの多い. $\times 25,000$

圀10：去勢後 7 日の前立腺瘦稩胞：Terminal bar (Tb). Desmosome (Des) 変化なし。系粒体 (M) は 脚化が強い。クリスタも破買されて短い。粗面小胞体 （rER）は膨化したものや稩切化されたものがみられ る. R N P 顆粒も消失している部分もあり。 $\times 17,600$

図11：去勢後 7 日の前立腺癌勫胞. 上部の核 $(\mathrm{N})$ は 核クロマチン (Nc) がみられるが下の核では不明瞭. 禾粒体（M）はほ:正常. $\times 15,000$

目12：去勢後 7 日の前立腺癌細胞. 系粒体(M)は電子 密度が高い. Cytoplasmic inclusion body (Cib) が多数 散在している.ゴルジ体 $(\mathrm{G})$ も変形している. $\times 13,000$

図13: 去势後 7 日の前立腺癌稩胞. 系粒体の電子密度 高く奇妙な型を示す。コルジ体 $(\mathrm{G})$ もばらばらになる. Cytoplasmic inclusion body (Cib) るみられる. 一般 に稩胞質基質の電子滵度低い, $\times 17,600$

四14: 去勢後 7 日の前立腺癌勫胞. 左下の核 $(\mathrm{N})$ は 核膜の破噮あり。系粒体（M）は伥化し,クリスラは小 胞状である。 $\times 18,400$

図15：去勢後 7 日の前立腺癌細胞. 核 (N) は核望に 乏しく小型である。系粒体（M）は浱縮され小さく不整 形をなす，粗面小胞体（rER）も細切化されている.こ の細胞を変性稩胞（D C) と呼ふ。図14の稩胞ヶ变性勫 胞に近い, $\times 13,000$

図16:去势後 7 日の前立腺癌稩胞. 系粒体 (M) の多 くは膨化し，クリスタは破壊されている，細胞内に Tonofilament がみられる. $\times 18,400$

図17：去势後 7 日の前立腺瘦間質. 線維牙稩胞 $(\mathrm{F})$ をとりまいて艮原楾稚（C）が多数みられる.その間に 小さな線維, 幼若翏原線維 (Ic) が存在している. 10,500

図18：去勢後14日の前立腺癌稩胞. 核 $(\mathrm{N})$ は小型で 核筫に乏しい，糸球体（M）は円形でクリスタはほとん ど見られない，膨化，細切化された粗面小胞体 (rER) が存在する。瞕原線 䧽 (C) が多い， $\times 15,600$

図19：去勢後14日の前立腺癌細胞. 米粒体 (M), 小胞 体 (rER), ゴルジ体 (G) は原形をとくめめてない. 翏 原楾䧽の增生が著しい。 $\times 13,000$

\section{考按}

前立腺癌は, 自律性という悪性腫瘍の性質を持つのみ でなく，ホルモン依存性という性質を兼ねそなえてい る。この性質を利用して行われている抗男性ホルモン療 法は臨床的にも病理組織学的にも非常に有効な方法と考 えられている。しかし抗男性ホルモン療法のらち去勢術 についての変化は病理組織学的にいまた明らかにされて いない部分がみられる．著者は電子顕微鏡を用い，正常 
前立腺, 前立腺肥大症腺腫, 前立腺癌, 去勢後 7 日, 14 日の前立腺癌を観察した。

これらの観察所見より, 次の二つの点について主に電 顕的な立場より考察してみたい.

（1）前立腺癌を他と比較してその特徴とする所を検 討する。

（2）去勢後の前立腺癌の変化を検討し，癌細胞の退 行変性及び間質の増生についての新しい所見を述べる.

(I) 前立腺癌の特徵

前立腺癌との比較でラット Ventral prostate. 正常前 立腺，前立腺肥大症腺腫をとりあげてみたい。

ラット Ventral prostate についての電顕的研究はす でに多数発表されている (Braunsteiner ${ }^{5)}$, Brandes \& $\mathrm{Groth}^{10)}, \mathrm{Harkin}^{22)}$ ，山口 ${ }^{59)}$ )。 その細胞は円柱状で注ぼ 単層である，核は基底部にあり，核上野から尖端部にか けて多数の細胞質小器官がみられる.最も著明な所見は 粗面小胞体で同心円状に層状配列をなしている.

ヒト正常前立腺の場合, Brandes et $\mathrm{al}^{8)}(1964)$ 6 観察 している如く，ラットに見られた層状配列をなす粗面小 胞体はみられない，むしろ核上野に粗面小胞体がみられ るのが特徵である.基底膜に関しては,光顕像では一般に 不明膫であるとされているが (Maximow \& Bloom ${ }^{34)}$ ), 電顕像からはつきりと存在しているのが確認された。上 皮細胞でありながら腺細胞の特徵を持つていない，いわ ゆる基底細胞については Brandes et $\mathrm{al}^{8}{ }^{\text {) }}$ (1964) はBasal cell と呼んでいる. Frank \& Barton ${ }^{17)}(1960)$ もット Ventral prostate でこの細胞を観察し Basal cell と呼 んでいる. 橴谷 ${ }^{48)}$ (1963) はラツトで Basket cell と呼 び，発達の悪い筋上皮或は老衰細胞と考えている。しか しこの細胞の機能，成因については明らかではない. 前立腺肥大症腺腫の細胞は一見して正常細胞と区別が つかない. Takayasu \& Yamaguchi ${ }^{53)}$ (1962) 飞よれ ば，癌にくらべ肥大症では核小体, 杀粒体の変化が少い, Brandeset et $\mathrm{al}^{8)}$ (1964) は肥大症の特徵は腺細胞之基底 細胞の細胞間隙の膨化であるとし，これらは Pinocyte の役目をしていると解釈している.

前立腺癌の電顕像を発表しているのは兽田 ${ }^{50)}$ (1960)， Takayasu \& Yamaguchi $^{53)}$ (1962) Brandes et al ${ }^{8)}$

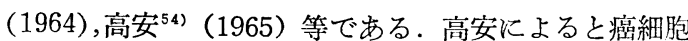
の特徵として 糸粒体の 增加及び 多態性を挙げている. Brandes et al は糸粒体の変性をのべ，特に未分化癌の 時に，禾粒体は膨化して大きくなる。クリスタも破墂， 消失がみられると報告している。
著者の観察した前立腺癌では核は正常前立腺や前立腺 肥大症に比し. 核膜の不規則性, すなわち核の型が変化 に富んでいる. 光顕でみられる indentation, infolding, furrowing, budding (Koller $\left.{ }^{311}\right)$ に当たるものである. 正常では認めら礼ない核クロマチンが増加し，核小体と 区別がつかない，Bernhard ${ }^{677)}(1963)$ は癌細胞での特 徵は核クロマチンであるとのべ，正常では核膜附近に稀 にしか見ることができないが，癌では数も大きさも増加 するということを明らかにしている. Theron et $\mathrm{al}^{56)}$ （1962）は癌では核内に細胞質ありと報告しているが， これは Infolding が強いことを示すこの様に癌細胞の 核では infolding が強いこと，核クロマチンが多数存在 していることは, 分裂能が高まつていることを意味して いる之想像する。

細胞膜については前立腺癌では著明な変化はみられな かつた. Terminal bar, Desmosome の破壊像はなく, 数も正常前立腺にくらべ少いといらことは見られない。 しかし Interdigitation は少い様であつた。悪性腫瘍は 一般に表面がつるつるになる傾向があり，䇟接細胞之離 れやすくなつている。これは癌細胞の転移の原因にもな つているという (Vogel, Sirtori \& Morano, HinglaisGuilland et $\left.a^{58)}\right)$.

前立腺癌の系球体については, 今回の観察の結果, 正常 前立腺, 前立腺肥大症腺腫にくらべ，系粒体は変化に 富んでいることが明らかになつた．系粒体は数が增加 し，やや膨化し，一部にクリスタの断裂菧みられる. Brandes et $\mathrm{al}^{8)}$ (1964) も前立腺癌の未分化癌では糸粒 体の変化が最も大きな特徵であつたと記載している.

Bernhard")（1963）は悪性腫場の系粒体は一般に形や大 きさに変化が多いと述べている. Theron et $\mathrm{al}^{56)}(1960)$ も Hepatome の系粒体について記し大きな型で電子密 糸粒体と，小さくて電子密度の高い糸粒体の二度の低い 種類があると発表している．この糸粒体の変化は著者の 去勢後の糸粒体の変化に似ていると思われる. Tandler \& Schipkey ${ }^{55)}$ (1964）は良性腫瘍の 系粒体の変化とし て膨化及び Intermitochondrial granule の消失をとり あげ，系粒体が Myelin 様に変化したものが観察された とのべている。しかし糸粒体は生理的, 病的状態で非常

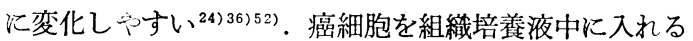
と糸粒体の不整は消光，正常の糸粒体が現われる（Sch ipkey $\left.{ }^{46}\right)$ ）という事実があり， 系粒体の変化が悪性化の 原因であるか結果であるか恃不明である。

一症例に図 9 に示した顆粒 Cytoplasmic inclusion を 
もつた細胞が存在した。これは現在でも成因は不明で ある.Schulz ${ }^{47)}$ (1960) が最初に記載し Virus様のもの と結論した，その後も少数例ではあるが，発表されてい る. Barland et $\mathrm{al}^{4)}$.(1964) は Lysosomeであると述べ ている. Athanassiades et $\mathrm{al}^{22}$.（1965）によれば，貧 食細胞により消化された巨大細胞の顆粒であるとされて いる.これらの顆粒は直接癌とは関係ないと思うが，前 立腺癌で発見されたのは始めてである.

ゴルジ体についてはTheron et al ${ }^{56)}$ (1962) は Hepatomeでは発達していると述べ, Buerger et $\mathrm{al}^{11)}(1962)$ は乳癌では発達が悪いと記している.Bernhard ${ }^{7)}$ (1963) は一般に悪性腫瘍(特に未分化の悪性腫瘍)では発達が悪 いか無いことが多いが, 乳癌の様なホルモン依在性のも のはゴルジ体は発達するのではないかと記載している. 前立腺癌もホルモン依存性の癌であるからゴルジ体は発 達してもよいと考兄られが，著者の観察した所では正 常と変りないと思う.

著者は正常前立腺の特徵として粗面小胞体をあげた． 前立腺癌では滑面小胞体は小胞状空胞となつて細胞質全 域に存在する. 粗面小胞体はやや膨化, 細切化されてい るが比較的形態の維持されたものが多い. 前立腺癌では 正常前立腺に近い粗面小胞体が残つているということは 前立腺癌の性ホルモン依存性と, 何らかの関係があるの ではないかと想像する。

以上前立腺癌の特徵をまとめてみると, 最も正常前立 腺と異なる所見は核及び系粒体である。核は他の悪性腫 瘍と同様な所見を呈した．細胞質では糸粒体の型及び数 が正常前立腺, 前立肥大腺腫にくらべ变化に富んでいた。 粗粗面小胞体は癌では比較的発達して打り, あまり強い 変化を示さず，正常前立腺に近い形態を示していた。

（II）前立腺癌の去勢時の変化

抗男性ホルモン療法による前立腺癌の光顕像では, 癌 細胞の退行変性及び間質の増生が観察されている ${ }^{1)}$. 退 行変性としては (1)癌細胞の大きさ, 数の減增 (Fergu$\left.\operatorname{sson}^{18) 19}\right)$ ，（2)核濃縮，核融解 $\left(\right.$ Schenken $\left.{ }^{45}\right)$ ，（3）細胞 質の空胞化 (Schenken ${ }^{45}, \mathrm{Heckel}^{23)}$ )，(4)結合織性の増 殖を伴う腺様構造の消失 (Fergusson $\left.{ }^{19}\right)$ 等があげらら れている. 馬場3（1959）は抗男性ホルモン療法による 変化は癌細胞の退行変性及び間質の増生であると述べ, 扁平上皮化生についてもつけ加えている. 前立腺癌に去 勢術を行つた時の光顕像に現われる変化として，馬場は 特に癌細胞の退行変性を強調している.

現在までに去勢の影響を電顕的に観察したものに，ラ
ツト Ventral prostateを用いてHarkin ${ }^{22)}$ (1957) 山ロ ${ }^{59)}$

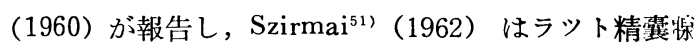
用いて去勢の影響を見ている．Harkin によれば去勢後 24㭙間で小胞体の膨化がわれ，2 日目にはゴルジ体の拡 張，4 日後には小胞体が破壊されてくる. それにひきつ 今゙き細胞質の減少がみられる.山口はラット及びマウス を用い観察を行つた結果, 特に目立つ変化は粗面小胞体 の変化があり, 2 日目に抬張, 以後 5 日目頃よりやや膨 化するが数は減少する.10日目には数は増々減少し形も 萎縮するという。

Groth \& Brandes ${ }^{21)}$ (1960)はラツトVentral prostate で Estrogen の影響をうけるのは小胞体であると述べ, 小胞体の破壊に伴い Glycin-2-C ${ }^{14}$ の取込みが 4 日目に なると半分に減少すると報告している。すなわち女性木 ルモンにより蛋白合成が阻害されたことを示している. 渋谷 ${ }^{48)}$ (1963) はラットに男性ホルモンであるTestosterone propionate を投与し, 投与量の増加と共に, Multivesicular body, 糸粒体の肥大をみたが著明な変化は小 胞体の拡張であつたと記述している。これらよりラット Ventral prostate が性ホルモンの影響をらけるのは粗面 小胞体であると言える。

前立腺癌の場合, 著者の観察では著明な変化は細胞質 の小器官で特に系粒体, 小胞体の变化が著しく見られ た．且つその変化は一様に扣こるのではなく，ある細胞 では強く, 他の細胞では変化が少く, 各細胞で変化の段 階が異つている.

系粒体は正常に近いのは少く，ほとんどのものが変化 している.ある細胞では系粒体は膨化し，円形になりそ の中にあるクリスタは断裂し小胞状になつている. 又他 の細胞では系粒体は小さく濃縮した型をなす． Trump et $\mathrm{al}^{57)}$ (1965) はマウスの肝蔵に necrosis をおこさせ 糸粒体の変化を観察した. 寸なわち 5 分では変化せず, 1 時間で輪郭の不整, 奇妙な形態, 膨化を示すが, 2 時 間程でクリスタの破壊が㧊こり, 小さくなり系粒体の笔 子密度が高くなり，4時間で完全に破壤されると述べて いる.この論文と対比すると観察された糸粒体は 1 時間 から 2 時間 necrosis をおこさせた時の変化とほぼ一致 する。

小胞体の変化についての記載は少い.上記のTrump ${ }^{57}$ も 2 時間後に小胞体の 膨化, 細切化を観察している. Cook et al ${ }^{12) 13)}$ (1965) はラットの腎蔵を autolysisさ せ変化を観察した所，小胞体の変化として 4 時間後に 膨化, 細切化がおこり円い空胞に化すと述べている. 著 
者の所見では処置前比較的よく発達していた粗面小胞体 は数が少くなり, 一部膨化し, 多くは細切化され強い変 化をらける。 ラット Ventral prostate に於ては粗面小 胞体が男性ホルモンの作用の場と考兄られている（Ha$\left.\mathrm{rkin}^{22)}\right)$. 前立腺癌も正常前立腺之同様に粗面小胞体がよ く発達して括り, 去勢により粗面小胞体の変化, 及び free RNP 顆粒の減少といらことから, ヒトの場合も粗面小 胞体が, 男性ホルモンの作用の場であると推測される.

去勢後の細胞中で目につくのは変形した小器官 Cytoplasmic inclusion body (Cib)である.これらの中には 空胞中に小器官を入れているもの, Myelin 様に変化し たもの,等があり一様ではない. Novikoff et al ${ }^{36)}(1962)$ はラットの尿管を結紫し， 6 時間後の腎の近位尿細管細 胞中に系粒体の変形したものが現われるのに気付いてい る.彼は Cytolysome と名付け Lysosome の一種である と述べている. Rouiller et al ${ }^{42)}$ (1956)は肝細胞の崩壊 時系粒体と Microbody の移行型がみられることより系 粒体が変化して Microbody になると考兄ている. 最近 Ericosson et al ${ }^{16)}$ (1965) はこれらの Cytoplasmic inclusion body 対し新しい見解を出している. ラットの 近位尿細管中にみられるものに二種あり，一つは二重膜 でなく円く内容はほぼ dense である。もら一つは二重 膜で小器官が内部に含まれている．前者を Cytosome, 後者を Cytosegresome と呼んでいる. Cytosegresomeは 小胞体, 糸粒体の変形したもので, それが, Cytosomeに 変わるとのべ, 細胞質小器官特に系粒体の早いTurnover を示すものであると記している．彼等は電顕的組織化 学 ${ }^{20143)}$ を用いてこれらの小器官内に酸フオスファターゼ が含まれていることを証明している14115).

前立腺の酸フオスフアターゼ（以下 AP）に関し， Brandes")（1965）は電顕的組織化学でラットを用い AP を検出している，それによると AP は小胞体にて生成さ るという．Parkin ${ }^{39)}$ (1964) は前立腺癌は去勢により 組織内 AP は減少すると述べている.ラットとヒトとは 異なるかもしれないが, 去勢により小胞体が膨化, 細切 化されることは Brandes ${ }^{9}$ の実験より APを生成できなく なつたと考えることができる. しかし去勢後 APを含む Cytosome の増加がみられ, 今後の問題といえよう.

去勢の影響で核に变化が来る. ラットに於ける核の変 化は山口 ${ }^{59}$ が去勢後10日目頃より扢こる核質の疑集, 核 膜の不規則性をあげている. Cook et al ${ }^{12) 13)}$ は Autolysis の腎の変化として核濃縮, 核膜破壊を示している. 著者 の前立腺癌の去勢後では核質の稀薄化, 核膜の破壊が観
察された．核は固定時間等で著しく像が異つてくるので ただちに結論を出すことはできないが，観察の結果では 変性細胞と思われる細胞核はかなり変化していると推定 される。

一方生化学的な面で去勢の影響についての動物笑験が 行われている ${ }^{49}$. Kochakian ${ }^{30)}$ (1962) の成績によると 去勢マウスで前立腺の重量は65\%減少し，RNA はさら に $80 \%$ 減少する.すなわち細胞当りの RNA 含有量は減 少する。しかるに DNA は40\%の減少で細胞当りでは濃 くなるという．去勢による影響として最も大きなものは Microsomal RNAであり，すなわち小胞体である。これ らは著者の前立腺癌に怙ける結果とも一致すると思う。

前立腺癌の去勢の影響として間質の増生がとりあげら れる. Fergusson ${ }^{19)}$ (1946) 㳂抗男性ホルモン療法の時間 質結合織の増生は重要であると述べている。これらの間 質増生機転に関して Nicol et $\mathrm{al}^{35)}$ (1952) は次の様にの べている.モルモツトに Estrogen を投与した時特に去 勢を加光た場合, 肝, 脾, リンパ腺の網内上皮系を刺激 してMacrophage が前立腺に集り，これらが Fibroblast になつて、ここより膠原線維が生成され維維化を捛こす と記している．著者の観察した二種の膠原線維は大きい 方は巾が約 $700 \AA て ゙ ~ 300 \AA$ 前後に横絞があり，成熟した 膠原線維と見京されている. 小さい方は巾 $300 \AA$ 以下で 横絞は見られない。この線維は梶川 ${ }^{28) 29}$ とよれば㭃若な 膠原線維で Fibroblast の小胞体より生成されるという, 梶川はこれらを鍍銀染色を行つて電顕的に証明してい る.この幼若な線維に似たもの Tonofilament が去勢後 の細胞内に増加子るょうに思われる. 更に Rhodin ${ }^{41}$ （1963）によれば気管支上皮の基底細胞内にも Tonofilament は見られるという．この機構は病的状態に於て いつでも扁平上皮化生ができるということを意味すると 述べている.すなわち，去勢の影響によるものであると は断定できないか，この Tonofilamentをるつた細胞は 扁平上皮化生する可能性のある細胞であると言うことが できる。

以上電顕像に見られた去勢による变化を考察した．去 勢により前立腺癌は核及び細胞質の退行变性が括こり, 特に糸粒体,小胞体の変化が強く認められた. 又間質結合 織の增生がみられた.更に扁平上皮化生について加えた。

\section{結 語}

（1）正常前立腺細胞, 前立腺肥大症腺腫細胞, 前立 腺癌細胞, 去勢後 7 日, 14 日の前立腺癌細胞をそれぞ れ，1\%四酸化オスミウム・ベロナール緩衡液にて固定 
し, Epoxy樹脂に包埋し, 電子顕微鏡にて観察した。

（2）正常前立腺細胞は腺胿をとりかこむ単層上皮 で, 基質は基底膜で境されている。核は基底部にあつて 円形で核小体が存在し，染色質はみられなかつた。細胞 質には糸粒体, 小胞体, 分泌器官が存在し, 特に粗面小 胞体がよくみられた。 基底部に腺細胞と異なる基底細胞 が見出された。

（3）前立腺肥大症腺腫細胞は正常細胞に似ている. ただ核はやや不規則な型を示し，染色質がみられた．細 胞質の小器官は変化は認められなかつた。

（4）前立腺癌細胞にあつては細胞の配列が乱れ，基 質と間質が入りまじる．核は不整形で核クロマチンが核 内に散在していた。細胞質では系粒体の膨化が目立ち， クリスタの断裂がみられた。 小胞体は一部変化している が，多くは正常に近い型を示した. ゴルジ体も正常であ つた.

（5）去勢後 7 日，14日の前立腺癌では癌細胞の退行 変性及び, 間質の増生が認められた。退行変性として, 核は一部で破壊像がみられたが，変化福乞れほど強くな く, 細胞質に著しい変化が認められた。釆粒体は強く変 化し，膨化のため円型になり，クリスタも破壊されてい た。ある禾粒体は濃縮して小型になつていた．小胞体も 変化し，一部膨化,多くは細切化され，RNP顆粒も消失し ている部分も存在した. 細胞質内 free RNP 顆粒も減少 した.去勢後14日になるとこの傾向は特に強く現われた。 ゴルジ体が認められた. Cytoplasmic inclusion body も 多数出現し増加していた. 間質の増生に関しては, 膠原 線維の幼若線維の出現がみられ, 去勢勢後に間質膠原線 維が増加することが認められた．尚去勢後にみられる扁 平上皮化生る電䫓的に観察された。

（6）前立腺癌の特徵として異常な核, 変形した糸粒 体をとり上げ，正常前立腺に類似している点として粗面 小胞体をとり上げた．去勢により前立腺癌細胞は系粒 体, 粗面小胞体の著しい変化を呈した. 又粗面小胞体は 男性ホルモンと何らかの関係をるつているであるらと推 論した。

稿を終るに臨み, 終始御懇篤な御指尊, 御鞭塳を賜り 且つ御校閲を原 5 した恩師高安久雄教授, 第 2 生理学教 室内薗耕二教授に澡く感謝の意を表します。併せて御助 言御協力を睗れた教室員各位の御好意に深く感謝致しま す.

（本論文の要旨は昭和 40 年 5 月第 53 回日本泌尿器科学 会総会と拈いて発表した。尚来たる昭和 41 年 4 月第 22 回
日本電子顕微鏡学会及び昭和 41 年 8 月第 6 回国際電子顕 微鏡学会に於て発表予定である）。

\section{交献}

1) Anderson, W.A.D.: Pathology, C.V. Mosby Co., 1961.

2) Athanassiades, T.J., Herman, H. and Henninger, G.R.: Lab. Invest., 14, 409, 1965.

3）馬場弘二郎：日泌尿会誌，50,1113, 1959.

4) Barland, P., Novikoff, A.B. and Hamerman, D.: Amer. J. Path., 44, 853, 1964.

5) Braunstiener, H., Fellinger, K. and Pakesch, F.: Wien. Klin. Wchschr.,67, 761, 1955.

6) Bernhard, W. and Granboulan, N.: Exptl. Cell Res. Suppl, 9, 19, 1963.

7) Bernhard, W.: Progr, exp. Tumor Res., vol. 3, Karger Basel/ New York, 1963.

8) Brandes, D., Kirchheim, D. and Scott, W. W.: Lab. Invest., 13, 1541, 1964.

9) Brandes, D.: J. Ultrastruct. Res., 12, 63, 1965.

10) Brandes, D. and Groth, D.P.: Exptl. Cell Res.,23, 159, 1961.

11) Buerger, L. and Scarpelli, D.G.: Fifth International Congress for Electron Microscopy, vol. II, Academic Press, New York and London, 1962.

12) Cook, M.L., Osvaldo, L., Jackson, J.D. and Latta, H.: Lab. Invest., 14, 623, 1965.

13) Cook, M.L., Osvalde, L., Jackson, J.D. and Latta, H.: Lab. Invest., 14, 635, 1965.

14) Ericsson, J.L.E. and Trump, B.F.: Lab. Invest., 13, 1427, 1964.

15) Ericsson, J.L.E. and Trump, B.F.: Histochemie, 4, 470, 1965.

16) Ericsson, J.L.E and Trump, B.F.: Lab. invest., 14, 1341, 1965.

17) Franks, L.M. anc Barton, A.A.: Exptl. Cell Res., 19, 35, 1960.

18) Fergusson, J.D. and Pagel, W.: Brit, J. Surg. 33, 122, 1945.

19) Fergusson, J.D.: Lancet, 251, 551, 1946.

20) Goldfisher, S., Essner, E. and Novikoff, A. B.: J. Histochem. Cytochem., 12, 72, 1964.

21) Groth, D.P. and Brandes, D.: J. Ultrastruct. Res., 4, 166, 1960.

22) Harkin, J.C.: Endocrinol., 60, 185, 1957.

23) Heckel, N.J. and Kretchmer, H.L.: J.A. M.A., 119, 1087, 1942.

24) Hruban, Z., Spargo, B., Swift, H., Wissler, R.W. and Kleinfield, R.G.: Amer. J. Path., 42, 657, 1963.

25) Huggins, C. and Hodges, C.V.: Cancer Res., 1, 293, 1941. 
26) Huggins, C.: Ann. Surg.,115, 1192, 1942.

27) Huggins, C., Stevens, R.E. and Hodges, C. V.: Arch. Surg., 43, 209, 1941.

28）暒川欽一郎：綜合医学, 14,65, 1957.

29) 暒川欽一郎：最新医学, 16, 1767, 1961.

30) Kochakian, C.D. and Harrison, D.G.: Endocrinol., 70, 99, 1962.

31) Koller,P.C.: Exptl. Cell Res., Suppl. 9,3, 1963.

32）黑住一昌 : J. Electronmicroscopy, 14,12,1965.

33) Luft, J.H.: J. Biophs. Biochem. Cytol., 9, $409,1961$.

34) Maximow, A.A. and Bloom, W.: a Text Book of Histology., W.B. Saunders Co., Philadelphia and London.1952.

35) Nicol, P.T., Helmy, I.D.and Abou-zikry, A.,: Brit. J. Surg.,40, 166, 1952.

36) Novikoff, A.B. and Essner, E.: J. Cell Biol., 15, 140, 1962.

37) Novikoff, A.B. and Essner,E.: Federation Proc., 21, 1130, 1962.

38) Novikoff, A.B.: Lysosome, a Ciba Foundation Symposium, Churchill, Ltd., London, 1963.

39) Parkin, L., Bylsma, G., Tone, A.V., Drew, D. and Madden, R.J.: J. Histochem. Cytochem., 12, 288, 1964.

40) Palade, G.E.: J. Exp. Med., 95, 285, 1952.

41) Rhodin, J.A.G.: an Atlas of Ultrastructure,, W.B. Saunders, Co., Philadelphia and London, 1963.

42) Rouiller, C. and Bernhard, W.: J. Biophs. Biochem. Cytol., Suppl. 2, 425, 1956.

43) Sabatini, D.D., Bensch, K. and Barnett, R. J.: J. Cell Biol., 17, 19, 1963.
44) Sabatini, D.D., Miller, F. and Barnett, R. J.: J. Histochem. Cytochm., 12, 57, 1964.

45) Schenken, J.R., Burns, E.L. and Kahle, P. J.: J. Urol.,48, 99, 1942.

46) Schipkey, F.H., et al.: Progr. exp. Tumor Res. vol. 3.ょり引用.

47) Schulz, H.: Klin. Wschr., 38, 912, 1960.

48）淽谷宗則：日泌尿会誌，54，111, 1963.

49) Sheppard, H., Tsien, W.H., Mayer, P. and Seymour, G.: Biochem. Biophys. Res. Commun., 15, 546, 1964.

50）留田冬雄: 米子医誌, 11, 435, 1960.

51) Szirmai, J.A. and Van der Linde, P.C.: Fifth International Congress for Electron Microscopy, vol II, Academic Press, New York and London,1962.

52) Svoboda, D.J. and Manning, R.T.: Amer. J. Path., 44, 645, 1964.

53) Takayasu, H. and Yamaguchi, Y.: J. Urol., 87, 935, 1962 .

54）高安久雄：日本内分泌学会雑誌，40, 1523, 1965.

55) Tandler, B. and Schipkey, F.H.: J. Ultrastruct. Res., 11, 292, 1964.

56) Theron, J.J., Pepler, W.J. and Liebenberg, N.: Fifth International Congress for Electron Microscopy, vol. II, Academic Press, New York and London, 1962.

57) Trump, B.F. Lab. Invest., 14, 343, 1965.

58) Vogel, et al.: Progr. exp. Tumor Res. vol. 3.より引用.

59）山口美登：日泌尿会誌, 51, 1068, 1960.

60) Watson, M.L.: J. Biophs. Biochem. Cytol., $727,4,1958$.

（昭和 40 年12月 9 日受付） 